\title{
THE PYGMY WHITEFISH, COREGONUS COULTERI, IN LAKE SUPERIOR
}

\author{
Paul H. Eschmeyer \\ U. S. Department of the Interior, Fish and Wildlife Service \\ AND \\ Reeve M. Bailey \\ Museum of Zoology, University of Michigan \\ Ann Arbor, Michigan
}

\section{Contents}

\begin{tabular}{|c|c|}
\hline & \\
\hline$\ldots \ldots \ldots$ & \\
\hline rials and methods .... & \\
\hline ic placement & \\
\hline Coregonus (Prosopium) coulteri Eigenmann and Eigenmann-pygmy whitefish & \\
\hline 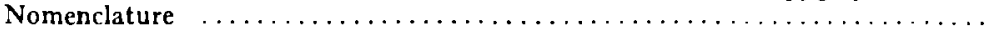 & \\
\hline 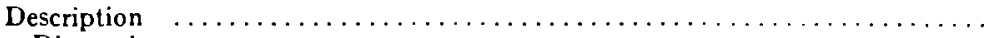 & 167 \\
\hline$\ldots \ldots \ldots \ldots$ & 167 \\
\hline erior stock $\ldots \ldots \ldots \ldots \ldots \ldots \ldots$ & \\
\hline 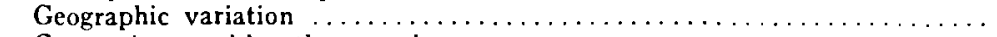 & \\
\hline isons with other species & 16 \\
\hline ion and abundance .... & \\
\hline ral dist & \\
\hline undance in Lake Superior ................... & \\
\hline 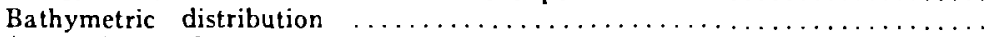 & \\
\hline growth & \\
\hline aw Bay & 181 \\
\hline iwit Bay, Isle Royale & 182 \\
\hline The Apostle Islands .... & \\
\hline$\ldots \ldots \ldots \ldots \ldots \ldots$ & \\
\hline vea & \\
\hline Id Lakes, Mo & \\
\hline$\ldots \ldots \ldots \ldots \ldots \ldots \ldots$ & \\
\hline tion & 1 \\
\hline urity & 1 \\
\hline Sex & $i$ \\
\hline undity & \\
\hline ality of spawning & 2 \\
\hline$\ldots \ldots \ldots \ldots$ & \\
\hline es. & 1 \\
\hline edur & \\
\hline & \\
\hline
\end{tabular}

\begin{abstract}
Bottom trawling by the U. S. Fish and Wildlife Service motor vessel Cisco in Lake Superior in 1952-1953 revealed a large population of a tiny whitefish, Coregonus (Prosopium) coulteri, which has been reported previously only from northwestern North America. The hiatus in range, from Lake Superior to the
\end{abstract}


Columbia River basin, is the greatest known for a North American freshwater fish. Although minor structural differences characterize the disjunct populations of the pygmy whitefish, these are not deemed worthy of nomenclatorial recognition. Comparisons with related species indicate that the pygmy whitefish is distinctive in the small size, large scales, few vertebrae, few pyloric caeca, and in other characters.

The pygmy whitefish is widely distributed in Lake Superior, especially in semiprotected bays, such as Keweenaw Bay which yielded about 68 percent of the 1,623 specimens caught. The bathymetric range was 10 to 49 fathoms, with maximum abundance at the 25- to 39-fathom interval. Average length of fish increased progressively with water depth, chiefly because the number of yearlings declined from 100 percent at 10-14 fathoms to none at $45-49$ fathoms.

The average total length of pygmy whitefish caught by trawling was 3.4 inches (range 1.2 to 5.7). Extraordinarily slow growth was revealed by the examination of scales. Two fish from Keweenaw Bay, both nearing the end of their eighth growing season, were only 5.4 inches long. Compared to Keweenaw Bay, growth rate was about the same near Laughing Fish Point, faster in the Apostle Islands (and in Bull and McDonald Lakes, Montana), and slower in Siskiwit Bay, Isle Royale. Females grew more rapidly than males after the second year and had a longer life span.

All male pygmy whitefish were mature at the age of 2 years and a total length of 3.6 or more inches. Most females were mature at 3 years and 4.2 inches; all older females were mature. Mean egg production was 362 (range, 93 to 597 ) per fish and 26 per gram of total weight for fish from 3.4 to 5.9 inches long. Spawning in 1953 occurred sometime in November or December.

Crustacea (principally ostracods and amphipods-copepods in the young) occurred in 106 of 112 pygmy whitefish stomachs and made up 77 percent of the total food volume. When available, fish eggs appear to be important in the diet.

Other cold-water fishes-cottids, ninespine sticklebacks, smelt, and four species of coregonines-were the most frequent associates of the pygmy whitefish. Lake trout and trout-perch were also taken with it at the same stations or in the same trawl hauls. Its closest relative in Lake Superior, the round whitefish, was not an ecological associate.

\section{INTRODUCTION}

One of the most comprehensive studies yet attempted on a sizable group of fishes over a considerable region, the monograph of the whitefishes of the Great Lakes (Koelz, 1929), presented a wealth of information on the taxonomy, morphometry, areal and bathymetric distribution, size, abundance, breeding habits, and variation of the 11 species known from the area. The possibility that any species was overlooked in this survey seemed remote. Yet the introduction of bottom trawling by the U. S. Fish and Wildlife Service motor vessel Cisco in 1952-1953 revealed an abundant population of a tiny whitefish, Coregonus coulteri, in Lake Superior. The small size accounts for the failure of earlier investigators to collect it, since this whitefish is not vulnerable to the commercial gill or impounding nets that are fished where it lives. The bathymetric distribution, from about 10 to 49 fathoms, accounts for the failure of the species to appear in shore collections taken with small-mesh gear.

The discovery of pygmy whitefish in Lake Superior is particularly fascinating because all previous records of occurrence are from the Pacific slope. The present new record reveals a gap of roughly 1,100 miles in the distri- 
bution. No other freshwater or terrestrial vertebrate (birds excepted) in North America is known to us to display such a strikingly disjunct range. In reporting the discovery of the species in Lake Superior we have felt impelled to compare this stock carefully with that from the Pacific slope. In addition, we contrast it with its closest relative in the Great Lakes basin, the round whitefish, Coregonus cylindraceus (termed Prosopium quadrilaterale by Koelz), and present information on occurrence within the lake, bathymetric distribution, size, growth, reproduction, food, and associates.

\section{Materials ANd Methods}

Pygmy whitefish were collected at 17 stations in Lake Superior (Table 1; Fig. 3) by dragging an otter trawl along the lake bottom. Most were caught in nets 35 feet wide at the wings and 36 feet long. Mesh sizes of the cotton netting ranged from $1 \mathrm{I} / 2$ and $2 \mathrm{r} / 2$ inches (extension measure) at the forward end to $1 / 2$ inch at the cod end. Ordinarily the trawl was lowered to the bottom, towed for 10 minutes (usually parallel to the contour), and then retrieved. Water depth over the area trawled was recorded by a fathometer, and station locations were determined by radar. ${ }^{1}$ The distance covered in a 10-minute haul depended partly on prevailing winds and currents, but probably averaged about $1 / 2$ mile. Fish caught were preserved in formalin immediately after collection. All measurements and weights given in this paper were made after preservation.

Morphometric measurements and counts have mostly been taken as described by Koelz (1929, pp. 305-308). Head length, as measured, includes the opercular membrane. The upper-jaw length was measured from the tip of the snout, apparently in the same way as Koelz measured the "maxillary." An orbital diameter is employed to replace the eyeball measurement used by Koelz. All rudimentary gillrakers are included in the count. Lateral-line scales were counted to the base of the caudal fin, irrespective of the position of the last pored scale; this count is not exactly equivalent to Koelz' method. For fin-ray counts all elements in the pectoral and pelvic fins are included. The last ray of the dorsal and anal fins is counted as double at the base (as recorded also by Koelz), but all anterior elements are included, no matter how short; thus the counts are taken in the same manner as by Dymond (1943) but are two or three higher than Koelz' tabulations, in which the first ray approached threefourths the length of the longest ray in the fin. Unbranched and branched rays are segregated, then summed (e.g., iii $+8=11$ ). The number and lengths of the unbranched rays in these fins vary erratically, and enumeration of all rays provides the most stable, hence probably the most reliable, count.

In addition to the Lake Superior specimens we have examined the following material of Coregonus coulteri:

1 A description of the Cisco and its navigational and research equipment was given by Moffett (1954). 


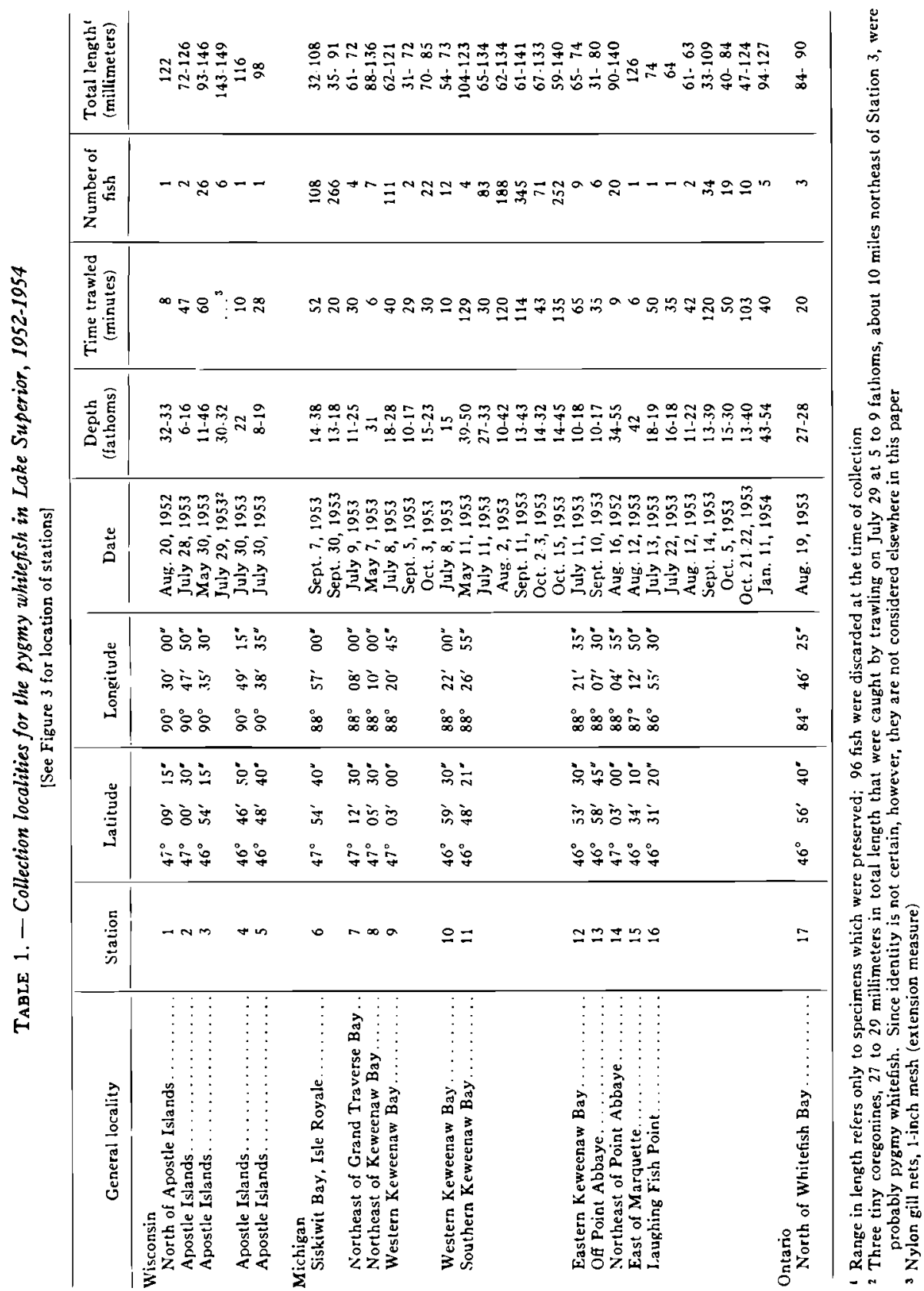


UMMZ 2167,941 , here designated as lectotype of Coregonus coulterii Eigenmann and Eigenmann, a tuberculate, adult male, 92.5 millimeters in standard length, collected in the Kicking Horse River, elevation 4,050 feet, Columbia River system, at Field, British Columbia, by Carl H. Eigenmann in 1892. (Data on the lectotype are given in Table 2.) This specimen together with four others, UMMZ 61,949, was formerly catalogued as Indiana University 4,446. Eigenmann's original collection consisted of over 100 syntypes. Others seen by us are USNM 44,875 (3 specimens) and USNM 64,089 (1). One specimen is now in the British Museum (Dymond, 1943, p. 203) and 7 are in the Stanford collection (Böhlke, 1953, p. 13). Although Evermann and Smith (1896, p. 290) and subsequent authors have specified USNM 44,875 as "type" of $C$. coulleri, this action does not constitute valid designation of a lectotype (Int. Comm. Zool. Nomen., 1953, pp. 72-77) since the lot referred to includes three specimens, as noted by Böhlke (1953).

USNM 126,910 (3), Lake Aleknagik, Alaska, August 2, 1911, G. Dallas Harma and July 20, 1909, M. C. Marsh.

SU 24,809 (1), Chignik River near weir, Alaska, June 11-19, 1928, Harlan B. Holmes.

SU 24,810 (3), Upper Chignik River, Alaska, June 7-8, 1928, H. B. Holmes.

SU 24,811 (12), Chignik River at coal mine, Alaska, August, 1924, Charles Petry.

BC, 54-423 (2), Lower Arrow Lake, sandy point opposite Renata, British Columbia, June 26,1949, T. G. Northcote.

SU 5,477 (2), Diamond Lake, Pend Oreille County, Washington, June, 1894, J. 0. Snyder. Diamond Lake was said by Snyder (1917) to be located in Stevens County, Washington, a statement repeated by other workers. There is a Diamond Lake in Pend Oreille County, and Clarence F. Pautzke, Chief, Fishery Management Division, Washington Department of Game, confirms our suspicion that this must be the lake intended.

MSU W53-2 (5) and UMMZ 167,942 (5), mouth of Ross Creek, Bull Lake, tributary to Kootenai River, near Troy, Lincoln County, Montana, December 26, 1952, J. B. Dillon.

MSU W53-3 (7) and UMMZ 167,943 (6), same locality, January 12, 1953, Kenneth Hays.

USNM 104,688 (2) mouth of Fish Creek, Lake McDonald, Glacier National Park, Montana, August 25,1935, L. P. Schultz and A. S. Hazzard.

USNM 101,606 (4), near mouth of McDonald Creek, Lake McDonald, Glacier National Park, Montana, probably late November 1935, C. L. Croghan.

USNM 102,375 (37), Lake McDonald, Glacier National Park, Montana, November 17, 1936, C. L. Croghan.

\section{Generic Placement}

European ichthyologists have long and consistently grouped the whitefishes other than Stenodus leucichthys in the single genus Coregonus. North American authors, in contrast, have for the most part adopted the segregation advocated by Koelz (1929) into three genera-Leucichthys, Coregonus, and Prosopium. Koelz keyed out the species (and genera) of whitefishes in each of the Great Lakes, defined the characters of each genus on the basis of the species present in that region, and evaluated the principal characters employed in whitefish taxonomy, again confining his critique to local species. Nowhere did he include extralimital forms in a clear definition of the genera. The differences between genera as stated may seem adequate, but each of two of the "genera" was represented by a single

2 Abbreviations for museum specimens are as follows: BC. University of British Columbia; MSU, Montana State University; SU, Museum of Natural History, Stanford University; UMMZ, Museum of Zoology, University of Michigan; USNM, United States National Museum. 
species then known in the Great Lakes fauna. How tenuous was the basis for the segregation of Prosopium may be illustrated by consideration of the characters of the pygmy whitefish. Koelz (1929) distinguished Prosopium (quadrilaterale) from the other whitefishes of Lake Superior in several characters. The pygmy whitefish agrees with Prosopium, as defined, in the single narial flap, the lack of vestigial teeth on the jaws and the roof of the mouth (although lingual teeth are present), the number of gillrakers, and the subterete body. C. coulteri agrees with Leucichthys and Coregonus but differs from Prosopium in the size of the exposed field of the lateralline scales (not conspicuously smaller than the adjacent rows); fits $\mathrm{Co}$ regonus better than Prosopium in shape of snout, size of upper jaw, length of mandible, ratio of pelvic length to pelvic-anal distance, and presence of nuptial tubercles on the head; and is intermediate between Prosopium and Coregonus in gillraker length. In our judgment the morphological basis for segregation of genera becomes untenable if extralimital species, which reduce even further the utility of the differentiating characters, are included. We, therefore, agree with the generic nomenclature of Berg, Järvi, Regan, Svärdson, Thienemann, and other European investigators, and with those recent American and Canadian ichthyologists (e.g., Shapovalov and Dill, 1950; Legendre, 1954; Wilimovsky, 1954) who have of late employed Coregonus (sensu lato). Also, we follow Regan (1914) and Berg (1940) in assigning the whitefishes to a subfamily, Coregoninae, of the Salmonidae.

\section{Coregonus (Prosopium) coulteri Eigenmann and Eigenmann- Pygmy Whitefish}

Coregonus coulterii.-Eigenmann and Eigenmann [not E. and G.-a typographical error], 1892, pp. 961-963 (original description; Kicking Horse River, 4,050 feet, Field, British Columbia). Evermann and Smith, 1896, pp. 288, 290-291 (description and comparisons; pl. 12; Kicking Horse River, Field, B. C.). Jordan and Evermann, 1896-1900, pp. 462-463, pl. 76 (compiled). Halkett, 1913, p. 48 (compiled). Cockerell, 1913, pp. 125-126 (scales).

Coregonus coulteri.-Eigenmann, 1894, pp. 105, 115, 119, 121, I32, pl. 6 (description; Kicking Horse River, Field and Golden, B. C.). Evermann and Goldsborough, 1,907, p. 99 (compiled). Jordan and Snyder, 1909, p. 430 (comparisons; Diamond Lake [Pend Oreille Co.], Washington). Jordan and Evermann, 1911, p. 41, fig. (compiled). Kendall, 1917 (description; Second Lake and stream connecting it with First Lake, Chignik [Alaska Peninsula], Alaska). Snyder, 1917 (preyed upon by kingfishers; Diamond Lake, "Stevens Co.," Washington). Snyder, 1919, p. 4 (compiled). Kendall, 1921 (size [maximum total length 198 millimeters]; description; food; Lake Aleknagik, Alaska). Wilimovsky, 1954, p. 282 (range).

Prosopium coulteri.-Jordan, Evermann, and Clark, 1930, p. 65 (compiled). Schultz, 1936, p. 139 (comparisons; range). Schultz, 1941, pp. 8, 24-25, 39, fig. (characters; Fish Creek and McDonald Creek, tributaries to Lake McDonald, Glacier National Park, Columbia River basin, Montana). Wynne-Edwards, 1952, p. 16 (Sockeye Lake on the upper Alsek, $60^{\circ} 30^{\prime} \mathrm{N}$., $137^{\circ} 38^{\prime} \mathrm{W}$, Yukon Territory; records compiled). Weisel and Dillon, 1954, pl. 1 (characters; natural history; Bull Lake, Lincoln Co., Montana).

Prosopium coulterii.-Myers, 1932 (comparisons; Kicking Horse River, Field, British Columbia; Diamond Lake, Washington; Chignik River, Alaska). 
Dymond, 1943, p. 202-203 (characters). Dymond, 1947, p. 8 (characters; records, including Yukon [Territory]). Carl and Clemens, 1948 (and 1953), p. 35, figs. (compiled).

Prosopium snyderi-Myers, 1932 (original description; figure; holotype, SU 23,751, Crescent Lake, Olympic Peninsula, Washington). Schultz, 1936, p. 139 (comparisons; Lake Crescent, Olympic Peninsula, Washington). Myers, in Böhlke, 1953, p. 14 ("Crescent Lake may not have been the one on the Olympic Peninsula"). Coulter's whitefish.-Wynne-Edwards, 1947, pp. 12, 19 (Sockeye Lake, Alsek River system, Yukon Territory).

\section{NomenClature}

The original specific name coulterii is emended to coulteri in accordance with the recent decisions on patronymics established by the International Commission on Zoological Nomenclature (1953).

As indicated in the above synonymy, the type locality of Prosopium snyderi Myers cannot now be located with certainty. It is clear from the original account that this nominal species is close to $C$. coulteri. $P$. snyderi was said to differ from coulteri principally in certain body proportions, notably the longer fins, and in the larger scales. The lateral-line scale count, however, is well within the limits of variation for coulteri, as are most of the proportional measurements (Table 2). Sex dimorphism, especially in length of the fins, seems to account for the differences noted by Myers between snyderi, the male (as checked for us by N. J. Wilimovsky), and coulteri, the female (all specimens from the Chignik River, including the fish figured by Myers, are females). Since there remains no adequate basis for specific separation, Prosopium snyderi is placed in the synonymy of C. coulteri.

The Committee on Names of Fishes has expressed its disapproval of patronymics (e.g., Coulter's whitefish) as common names (Transactions of the American Fisheries Society, Vol. 84. Of the two alternative names suggested for the species we prefer pygmy whitefish to brownback whitefish as being briefer, more suitably descriptive, and more euphonious. The name pygmy whitefish was introduced by Weisel and Dillon (1954).

\section{DESCRIPTION}

Diagnosis.-Coregonus coulteri (Fig. 1) agrees with other species of the subgenus Prosopium in having a single internarial flap, in the presence of parr markings on the body in the young, in lacking teeth on the jaws, vomer and palatine, and in the terete body. The anterior lateral-line scales have the exposed field subequal to or only slightly smaller than the adjacent body scales. The scales are large, 54 to 70 along the lateral line, 31 to 40 around the body, and 16 to 20 around the caudal peduncle; dorsal rays 10 to 14 ; pyloric caeca 15 to 23 ; vertebrae 52 to 54 . The mouth is subterminal, the premaxillae are inclined downward and backward, and sometimes are almost vertical. The gillrakers number 13 to 20 , and are short to moderate in length, measuring from 1.3 to 2.1 percent of the standard length. The snout is broadly rounded in dorsal view. The mouth is of 


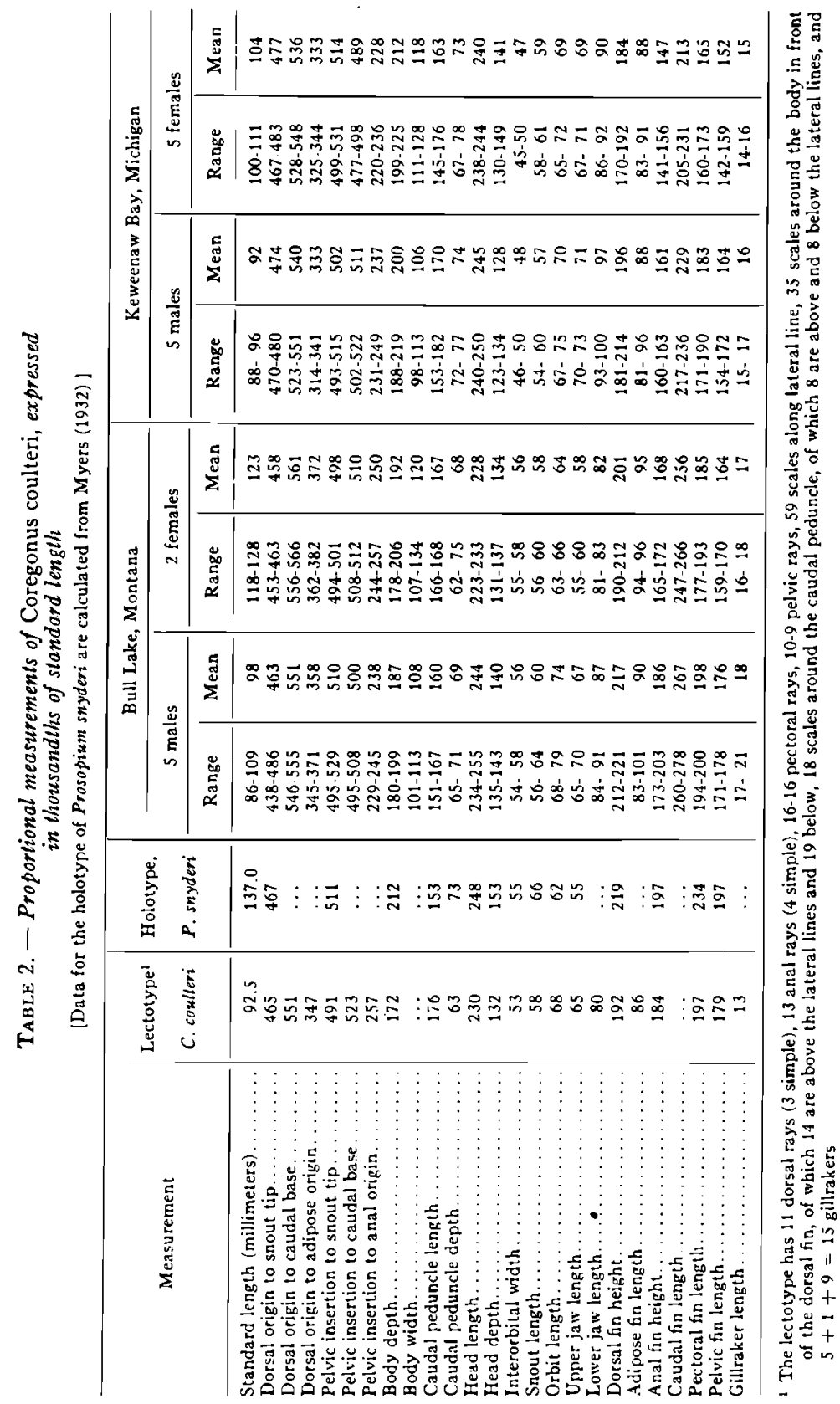




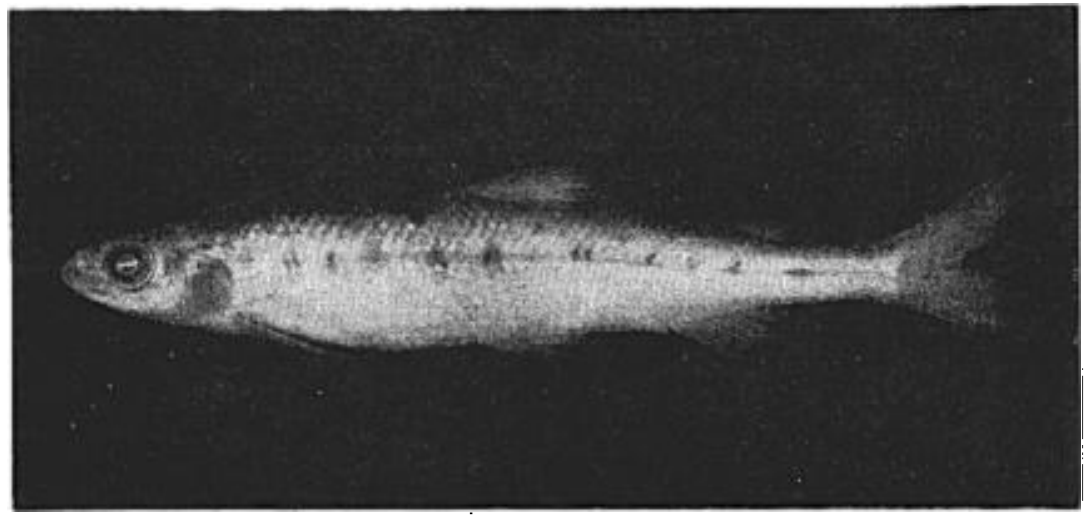

Froure 1.-Coregonus coulteri, a mature female, 4.8 inches long and 4 years old, collected October 15, 1953, in Keweenaw Bay, Lake Superior.

moderate size. The maximum total length recorded is less than 8 inches.

Description of Lake Superior stock.-Body proportions are presented in Table 2 and fin-ray, scale, and gillraker counts are given in Tables 3-7. Coregonus coulteri (Fig. 1) is apparently the smallest species of the genus; the largest specimen obtained in Lake Superior was 149 millimeters in total length although somewhat larger fish have been taken in the Pacific drainage (see Tables 15 and 17 for length distribution and size at maturity).

In measured specimens of the pygmy whitefish, females have large eggs and the body averages deeper and broader than in males (Table 2). The only other parts in which marked sex dimorphism is evident are the lengths (and heights) of the rayed fins; in all of these the males have the greater

TABLE 3. - Frequency distributions of counts of dorsal and anal fin rays in Coregonus coulteri

[All unbranched rays are included. $\mathrm{N}=$ number of specimens]

\begin{tabular}{|c|c|c|c|c|c|c|c|c|c|c|c|c|c|c|}
\hline \multirow{2}{*}{ Locality } & \multicolumn{5}{|c|}{ Dorsal rays } & \multirow{2}{*}{$\mathbf{N}$} & \multirow{2}{*}{ Mean } & \multicolumn{5}{|c|}{ Anal rays } & \multirow{2}{*}{$\mathbf{N}$} & \multirow{2}{*}{ Mean } \\
\hline & 10 & $1 \mathrm{I}$ & 12 & 13 & 14 & & & 11 & 12 & 13 & 14 & 15 & & \\
\hline $\begin{array}{l}\text { Alaska } \\
\quad \text { Lake Aleknagik. . . . . } \\
\text { Chignik River...... }\end{array}$ & $\ldots$ & $\ddot{8}$ & $\begin{array}{l}3 \\
7\end{array}$ & $\ddot{1}$ & $\begin{array}{l}\because \\
\therefore\end{array}$ & $\begin{array}{r}3 \\
16\end{array}$ & $\begin{array}{l}12.00 \\
11.56\end{array}$ & 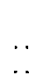 & $\begin{array}{l}2 \\
6\end{array}$ & $\begin{array}{l}1 \\
8\end{array}$ & $\ddot{2}$ & 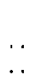 & $\begin{array}{r}3 \\
16\end{array}$ & $\begin{array}{l}12.33 \\
12.75\end{array}$ \\
\hline $\begin{array}{l}\text { Columbia drainage } \\
\text { Kicking Horse River. } \\
\text { Lower Arrow Lake... } \\
\text { Diamond Lake..... } \\
\text { Bull Lake......... } \\
\text { Lake McDonald... . } \\
\text { Lake Superior.......... }\end{array}$ & $\begin{array}{l}\cdots \\
\cdots \\
\cdots \\
\ldots\end{array}$ & $\begin{array}{r}5 \\
1 \\
2 \\
7 \\
14 \\
\\
23\end{array}$ & $\begin{array}{r}4 \\
1 \\
\because 2 \\
13 \\
5 \\
2\end{array}$ & $\begin{array}{c}. \\
\ldots \\
\cdots \\
\ldots \\
\ldots\end{array}$ & $\begin{array}{l}\cdots \\
\cdots \\
\cdots \\
1\end{array}$ & $\begin{array}{r}9 \\
2 \\
2 \\
23 \\
20 \\
\\
30\end{array}$ & $\begin{array}{l}11.44 \\
11.50 \\
11.00 \\
11.83 \\
11.40 \\
10.90\end{array}$ & $\begin{array}{c}1 \\
\cdots \\
\cdots \\
1 \\
1\end{array}$ & $\begin{array}{r}2 \\
1 \\
1 \\
10 \\
12\end{array}$ & $\begin{array}{r}5 \\
1 \\
1 \\
10 \\
5 \\
\\
18\end{array}$ & $\begin{array}{r}1 \\
\ldots \\
\ldots \\
2 \\
1\end{array}$ & $\begin{array}{l}. \\
\cdots \\
\cdots \\
\because \\
1\end{array}$ & $\begin{array}{r}9 \\
2 \\
2 \\
23 \\
20 \\
\\
25\end{array}$ & $\begin{array}{l}12.67 \\
12.50 \\
12.50 \\
12.57 \\
12.45 \\
13.20\end{array}$ \\
\hline
\end{tabular}


TABLE 4. - Frequency distributions of counts of pectoral and pelvic fin rays in Coregonus coulteri

[Counts for right and left sides are summed. $\quad \mathrm{N}=$ number of specimens]

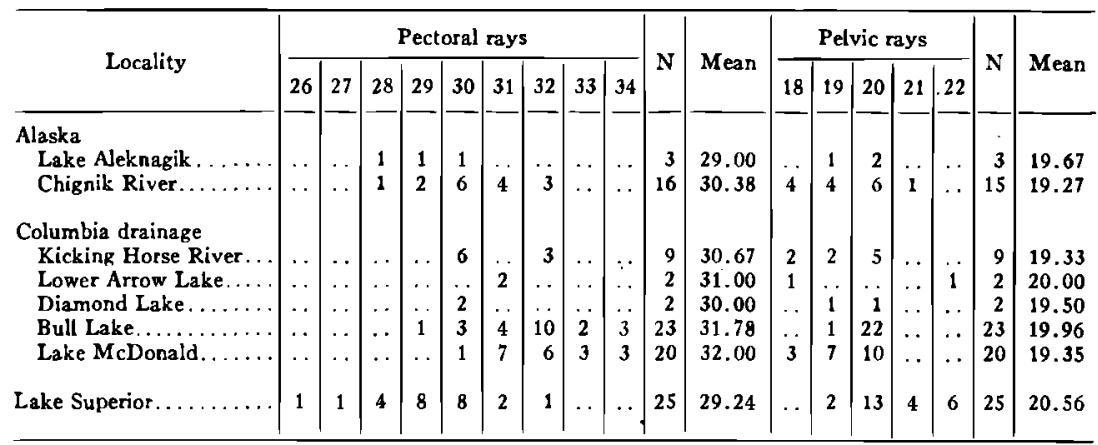

TABLE 5. - Frequency distribution of lateral-line scale counts in Coregonus coulteri [ $N$ =number of specimens]

\begin{tabular}{|c|c|c|c|c|c|c|c|c|c|c|c|c|c|c|c|c|c|c|c|}
\hline \multirow{2}{*}{ Locality } & \multicolumn{17}{|c|}{ Lateral-line scales } & \multirow{2}{*}{$\mathbf{N}$} & \multirow{2}{*}{ Mean } \\
\hline & 54 & 55 & 56 & 57 & 58 & 59 & 60 & 61 & 62 & 63 & 64 & 65 & 66 & 67 & 68 & 69 & 70 & & \\
\hline $\begin{array}{l}\text { Alaska } \\
\quad \text { Lake Aleknagik . . . . . . } \\
\text { Chignik River. . . . . . }\end{array}$ & $\begin{array}{l}\cdots \\
\ldots\end{array}$ & $\cdots$ & $\cdots$ & $\cdots$ & $\ddot{1}$ & $\begin{array}{l}\cdots \\
\cdots\end{array}$ & $\ddot{1}$ & $\ddot{2}$ & $\ddot{2}$ & $\begin{array}{c}1 \\
\ldots\end{array}$ & $\ddot{4}$ & $\ddot{2}$ & $\ddot{2}$ & . & $\ddot{1}$ & $\begin{array}{l}\cdots \\
\ldots\end{array}$ & $\begin{array}{l}2 \\
1\end{array}$ & $\begin{array}{r}3 \\
16\end{array}$ & $\begin{array}{l}67.67 \\
63.75\end{array}$ \\
\hline $\begin{array}{l}\text { Columbia drainage } \\
\text { Kicking Horse River. . } \\
\text { Lower Arrow Lake.... } \\
\text { Diamond Lake . . . . . . } \\
\text { Bull Lake.......... } \\
\text { Lake McDonald. . . . . . }\end{array}$ & $\begin{array}{l}\cdots \\
\cdots \\
\cdots \\
\cdots \\
\cdots\end{array}$ & $\begin{array}{c}\because \\
1 \\
\cdots \\
\ldots\end{array}$ & $\begin{array}{l}\cdots \\
\cdots \\
\cdots \\
4 \\
4\end{array}$ & $\begin{array}{c}1 \\
\ldots \\
\cdots \\
2\end{array}$ & $\begin{array}{l}1 \\
1 \\
2 \\
4\end{array}$ & $\begin{array}{c}3 \\
\ldots \\
\because \\
4 \\
2\end{array}$ & $\begin{array}{l}\cdots \\
\ldots \\
\because \\
4 \\
2\end{array}$ & $\begin{array}{l}\cdots \\
\cdots \\
3 \\
2\end{array}$ & $\begin{array}{c}3 \\
\cdots \\
\cdots \\
4 \\
1\end{array}$ & $\begin{array}{l}\ldots \\
\cdots \\
4 \\
1\end{array}$ & $\begin{array}{l}2 \\
\because \\
1 \\
1 \\
1\end{array}$ & $\begin{array}{c}\ldots \\
\ldots \\
\cdots \\
\cdots \\
1\end{array}$ & $\begin{array}{l}\cdots \\
\cdots \\
\cdots \\
\cdots\end{array}$ & $\begin{array}{l}\ldots \\
\ldots \\
\ldots \\
\ldots \\
.\end{array}$ & $\begin{array}{c}\cdots \\
\cdots \\
\cdots \\
\cdots\end{array}$ & $\begin{array}{l}\ldots \\
\ldots \\
\ldots \\
\ldots \\
\ldots\end{array}$ & $\begin{array}{l}\ldots \\
\ldots \\
\ldots \\
\ldots \\
\ldots\end{array}$ & $\begin{array}{r}9 \\
2 \\
2 \\
23 \\
20\end{array}$ & $\begin{array}{l}60.89 \\
56.50 \\
61.00 \\
60.70 \\
59.20\end{array}$ \\
\hline Lake Superior. & 2 & 6 & 5 & 4 & 4 & 5 & . & 2 & 1 & . . & $\cdots$ & $\cdots$ & . & $\cdots$ & $\cdots$ & . & & 29 & 57.14 \\
\hline
\end{tabular}

dimensions (Table 2). The increased size is presumably of adaptive significance since in breeding males (from Montana) these fins (as well as the head and body) are well supplied with nuptial tubercles; it is surmised that the fins function in the spawning embrace.

Like most other species of the subgenus Prosopium, Coregonus coulteri is terete; the body width is decidedly more than half the depth. Several related species (e.g., C. cylindraceus, C. williamsoni) have the snout notably shortened and conical, more or less sharply angulate in dorsal aspect (Koelz, 1929, p. 323, Fig. 12), in contrast to the bluntly rounded snout of the lake whitefish, Coregonus clupeaformis, and the size of the mouth is much smaller than in clupeaformis. The profile of the snout in coulteri is similar to that of clupeaformis, and the mouth is about the same size. The upper jaw of coulteri is contained in the head length 3.1-3.4 times (2.9-3.6 in clupeaformis from Lake Superior-data from Koelz, 1929); the 
TABLE 6. - Frequency distributions of body-circumference and caudal-peduncle scales in Coregonus coulteri

[ $\mathbf{N}=$ number of specimens]

\begin{tabular}{|c|c|c|c|c|c|c|c|c|c|c|c|c|c|c|c|c|c|c|c|}
\hline \multirow{2}{*}{ Locality } & \multicolumn{10}{|c|}{ Body-circumference scales } & \multirow{2}{*}{$\mathbf{N}$} & \multirow{2}{*}{ Mean } & \multicolumn{5}{|c|}{$\begin{array}{l}\text { Scales around } \\
\text { caudal peduncle }\end{array}$} & \multirow{2}{*}{$\mathbf{N}$} & \multirow{2}{*}{ Mean } \\
\hline & 31 & 32 & 33 & 34 & 35 & 36 & 37 & 38 & 39 & 40 & & & 16 & 17 & 18 & 19 & 20 & & \\
\hline $\begin{array}{l}\text { Alaska } \\
\text { Lake Alek } \\
\text { Clignik R }\end{array}$ & $\cdots$ & $\begin{array}{l}\cdots \\
\cdots\end{array}$ & 2 & $\begin{array}{l}1 \\
9\end{array}$ & 2 & $\begin{array}{l}2 \\
2\end{array}$ & $\ddot{1}$ & $\therefore$ & $\cdots$ & $\because$ & $\begin{array}{r}3 \\
16\end{array}$ & $\begin{array}{l}35.33 \\
34.44\end{array}$ & 1 & 1 & 13 & $\ddot{1}$ & $\begin{array}{r}3 \\
\cdots\end{array}$ & $\begin{array}{r}3 \\
16\end{array}$ & $\begin{array}{l}20.00 \\
17.88\end{array}$ \\
\hline $\begin{array}{l}\text { Columbia drainage } \\
\text { Kicking Horse River. } \\
\text { Lower Arrow Lake... } \\
\text { Diamond Lake...... } \\
\text { Bull Lake.......... } \\
\text { Lake McDonald. . . . } \\
\\
\text { Lake Superior.......... }\end{array}$ & $\begin{array}{l}\cdots \\
\cdots \\
\cdots \\
\cdots\end{array}$ & $\begin{array}{l}\ddot{1} \\
\cdots \\
\ddot{1}\end{array}$ & $\begin{array}{l}\cdots \\
\cdots \\
5 \\
6\end{array}$ & $\begin{array}{l}\cdots \\
\cdots \\
2 \\
8 \\
8 \\
1\end{array}$ & $\begin{array}{l}3 \\
1 \\
1 \\
9 \\
3\end{array}$ & $\begin{array}{l}. \\
\because \\
\sigma \\
\sigma \\
. . \\
7\end{array}$ & $\begin{array}{l}3 \\
\cdots \\
\cdots \\
1 \\
. . \\
2\end{array}$ & $\begin{array}{c}1 \\
. \\
\ldots \\
\ldots \\
\ldots \\
3\end{array}$ & $\begin{array}{l}1 \\
\cdots \\
\cdots \\
\cdots \\
\cdots\end{array}$ & $\begin{array}{l}1 \\
\cdots \\
\cdots \\
\cdots \\
.\end{array}$ & $\begin{array}{r}9 \\
2 \\
2 \\
23 \\
19 \\
21\end{array}$ & $\begin{array}{l}37.00 \\
33.50 \\
34.00 \\
34.83 \\
33.58 \\
\\
35.62\end{array}$ & $\begin{array}{l}. . \\
. . \\
. . \\
. . \\
. .\end{array}$ & $\begin{array}{l}2 \\
\cdots \\
i \\
2\end{array}$ & $\begin{array}{r}5 \\
2 \\
2 \\
11 \\
11 \\
3\end{array}$ & $\begin{array}{l}2 \\
\ldots \\
\because \\
8 \\
5\end{array}$ & $\begin{array}{l}2 \\
2\end{array}$ & $\begin{array}{r}9 \\
2 \\
2 \\
22 \\
20\end{array}$ & $\begin{array}{l}18.00 \\
18.00 \\
18.00 \\
18.50 \\
18.35 \\
19.46\end{array}$ \\
\hline
\end{tabular}

TABLE 7. - Frequency distribution of gillraker counts in Coregonus coulteri [Rudimentary rakers are included. $\mathrm{N}=$ number of specimens]

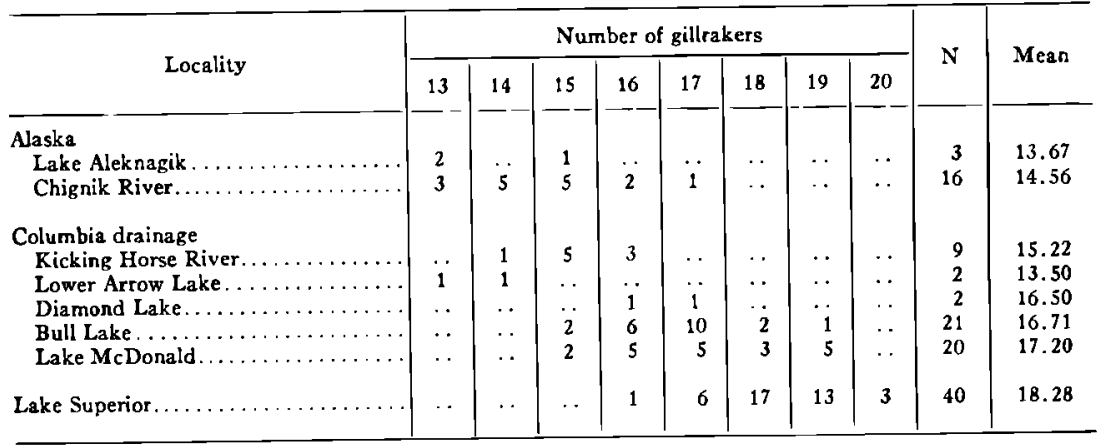

lower jaw is contained in the head 2.3-2.6 times (2.4-2.7 times in clupeaformis).

Both simple and branched rays of the dorsal and anal fins vary in number, and the arbitrary designation of the first ray on the basis of length is also unsatisfactory. There are usually 3 , occasionally 2 or 4 , unbranched dorsal rays, and usually 8 , sometimes 7 or 9, branched rays; the total dorsal count is 10 to 12 , usually 11 (Table 3 ). There are usually 3 or 4 , occasionally 5 , unbranched anal rays and 9 or 10 , infrequently 8 , branched rays; the total anal rays number (12) 13 or 14 . All of 10 specimens counted had 19 principal caudal rays $(17$ branched). The pectoral rays vary from 13 to 16 , and the pelvic rays from 9 to 11 (Table 4 ).

The scales are the largest in the family Salmonidae (Tables 5-6). The lateral-line scales number 54 to 62 . There are 33 to 38 body-circumference scales, of which 13 to 15 are above the lateral lines and 18 to 23 are below. 
The scales around the caudal peduncle number 18 to 20 , of which 8 or 9 are above the lateral lines and 8 or 9 are below. The breast and belly are fully covered with scales equal in size to those on the remainder of the body. Unlike Coregonus cylindraceus, the scales of the lateral-line row have the exposed field equal to or scarcely smaller than the scales of adjacent rows.

The gillrakers are rather short (6.5 to 8.8 percent of head length, 1.4 to 1.7 percent of standard length) but are relatively longer than in C. cylindraceus. The rakers number 5 to 7 on the upper limb, 1 at the angle, and 10 to 12 , most often 11 , on the lower limb. Total raker counts (all rudiments included) vary from 16 to 20 (Table 7). The branchiostegal rays in 10 specimens counted number $7-7$ in $3,8-7$ in 1 , and 8-8 in 6 .

The small number of pyloric caeca, perhaps the most distinctive structural feature of Coregonus coulteri, has apparently escaped prior notice. Ten Lake Superior specimens yield the following counts: 15 (1 specimen), 16 (2), 17 (2), 18 (2), and 19 (3). Three fish from Lake McDonald, Montana, have 20,21 , and 23 caeca. All caeca are simple. The minimum number of caeca for any other whitefish in the Great Lakes is 87 to 117 in Coregonus cylindraceus (Koelz, 1929). In vertebral count, too, the pygmy whitefish has a lower count than is usual among salmonids. Ten specimens have the following counts: 52 (2), 53 (7), 54 (1). The range of counts tabulated by Koelz (1929) among Great Lakes whitefishes is from 55 (in C. zenithicus and C. hoyi) to 63 (in C. clupeaformis and C. cylindraceus).

In adults the jaws, vomer, and palatine are toothless. The tongue, however, typically has several well developed, immovable teeth. These are imbedded but are readily revealed by removal of the soft tissue. Two large specimens of coulteri from Lake Aleknagik, Alaska, lack teeth on the tongue, but an individual from the Upper Chignik River, Alaska, has lingual teeth. Examination of several specimens of Coregonus cylindraceus from Lake Superior indicates the presence in this species also of one or a few teeth on the tongue. Koelz (1929) found no teeth in the mouth of this species.

In preservation Coregonus coulteri is pale tan, immaculate below and dusted lightly with melanophores on the lateral and dorsal surfaces of head and body. Along the lateral line is a series of about 8 to 11 subcircular parr marks that are more or less diffuse near their margins in half-grown individuals and become very indistinct in large adults (Fig. 1). The back is similarly marked by an irregular series of about 12 to 14 dark spots. A few additional spots are often present on the dorsolateral surface. There is a dark bar on the preorbital bone that parallels the upper jaw, and there are usually 1 to 3 dark spots on the top of the head behind the eyes.

Geographic variation.-In view of the great phenotypic and probably genotypic variability among whitefishes, it is to be anticipated that a species with a discontinuous range as extensive as that of the pygmy whitefish would exhibit notable local or regional variations in structure. Such observed variations have furnished the basis for the naming of a plethora of 
species and subspecies both in Eurasia and North America, with the addition of numerous infrasubspecies and even lesser named ranks among Old World coregonines. As expected, Coregonus coulteri is not structurally homogeneous throughout its range, but the strong similarity among the disjunct populations is more impressive than the relatively slight differences. Commonly the deviations present no consistent geographic pattern, giving rise to the suspicion that they are strictly local and represent genetic emphasis or reflect ecological differences rather than fundamental geographic divergence. More material, especially from the northwestern part of the range, is needed to resolve some aspects of the problem of geographic variation.

On the basis of the samples measured (Table 2), a number of body parts give evidence of variation. Notable among these are the lengths of the rayed fins, which also displayed sex dimorphism (p. 169). In each sex the fins of pygmy whitefish from Bull Lake, Montana, are higher (or longer) than those from Keweenaw Bay, Lake Superior. Only for the adipose fin do the differences seem to be of dubious reliability. The higher anal fin in the Bull Lake fish is especially notable. The type specimen of Prosopium snyderi is seen to agree closely with males of the Bull Lake stock in the dimensions of the median fins but has longer paired fins (it is possible that differences in mensural techniques are involved here). The lower jaw, and perhaps the upper jaw, average longer in the Lake Superior fish than in those from Bull Lake. The interorbital breadth is consistently greater in the Bull Lake whitefish. There are indications that the dorsal fin originates farther forward in the Bull Lake fish than in those from Keweenaw Bay, but the difference is slight, is subject to considerable overlap, and perhaps has no real significance.

In view of the notable differences in subsequent growth rate between stocks from Bull Lake and Keweenaw Bay (Fig. 4) there exists a strong possibility that early development, too, may differ in the same direction. If so, we may invoke a mechanistic explanation for the observed differences in fin and body proportions (Martin, 1949). Variations in developmental temperature are reflected in mean rate of growth and in size at which growth inflections occur. These in turn are important in the determination of the relative size of body parts, such as head and fins. In experimental lots of rainbow trout larger fins were produced by raising the temperature during early development (Martin, 1949).

Fin-ray counts of Coregonus coulteri (Tables 3-4) show some geographic variation in number of dorsal, anal, and pectoral rays but reveal nothing significant in pelvic-ray number. In the dorsal fin the usual number is 11 or 12 rays. At several localities these counts are equally frequent, but in Lakes McDonald and Superior there are usually 11 rays whereas in Bull Lake the modal count is 12 . No consistent geographic pattern is suggested. In the anal fin 12 and 13 rays are most frequent, usually 12 rays in Lake McDonald and 13 in Lake Superior. A pectoral count of 16 is most frequent in Bull and McDonald Lakes, Montana. Elsewhere in the Columbia River drainage, in Alaska, and in Lake Superior, the most common count is 15. 
In this as in the other fins, variation in the number of rays seems explainable as the result of local genetic emphasis or environmental modification. In any event the differences are not great, and the counts in the several populations overlap broadly.

There is no consistent positive correlation among the scale counts recorded (Tables 5-6). Lateral-line counts are maximal in Alaska, especially in Lake Aleknagik, are rather uniformly intermediate in the Columbia River system, and are lowest in Lake Superior. In the absence of certain of these stocks one might be inclined to recommend systematic partition of the others. In view of the rather complete gradation with extensive overlap between populations, however, such division seems pointless. Most populations usually have from 34 to 36 body-circumference scales, but the average number is considerably lower in McDonald Lake and higher in the Kicking Horse River-both in the Columbia basin. The most frequent caudal-peduncle scale count is 18 at all localities except Lake Aleknagik and Lake Superior, where counts of 19 and 20 are usual. As with the other counts the variations seem not to warrant special emphasis.

In the pygmy whitefish the number and the length of gillrakers are obviously correlated. In Alaska, the Kicking Horse River, and Arrow Lake the rakers are few (usually 13 to 16 ) and short (Table 7). Only one specimen was measured (Table 2), but the stubbiness of the rakers was noted during counting. In Diamond, Bull, McDonald, and Superior lakes the rakers typically number 16 to 19 , and are notably longer (Table 2). Although there is overlap in numbers and probably in length, the differences in gillrakers are more marked than those in other characters. In view of the geographic implications, with some Columbia basin populations like the Lake Superior fish and others similar to Alaskan stocks, it seems improbable that each of the two structural types has a separate, monophyletic ancestry.

The acquisition by a lacustrine whitefish, even if it is a benthic form, of more and longer gillrakers is probably of adaptive advantage in obtaining food. It may be noted that the populations with the better developed and more numerous gillrakers are lacustrine. Three of the stocks with fewer rakers are from rivers or lakes dominated by rivers. If we assume that the species was chiefly a stream fish originally, it seems probable that relatively rapid parallel modification in two or more lakes has produced an increased length and number of gillrakers.

Comparisons with other species.-Coregonus coulteri was regarded by Evermann and Smith (1896) as the most distinctive of the North American members of the genus, a characterization which is still at least close to correct. Among the species of American coregonines, coulteri is the smallest, has the largest scales, the minimal number of gillrakers (13 to 20, about as in cylindraceus), the fewest vertebrae, and has only about onefourth as many pyloric caeca as the lowest number reported among its congeners. The most obvious differences between the pygmy whitefish and the round whitefish, $C$. cylindraceus, are set forth in Table 8 . Many of these same characters serve also to distinguish coulteri from the Rocky 
Table 8.-Comparison of the two species of the subgenus Prosopium in the Great Lakes area [Proportional measurements, calculated arithmetically, are based on 10 specimens of Coregonus coulleri, 74 to 107 millimeters in standard length, from Keweenaw Bay, and 10 individuals of C. cylindraceus, 236 to 377 millimeters long, from Lake Superior (Koelz, 1929: p. 632). Data for C. cylindraceus that are taken wholly or in pact from Koelz (1929) are indicated by asterisks]

\begin{tabular}{|c|c|c|}
\hline Character & Coregonus coulleri & Coregonus cylindraceus \\
\hline 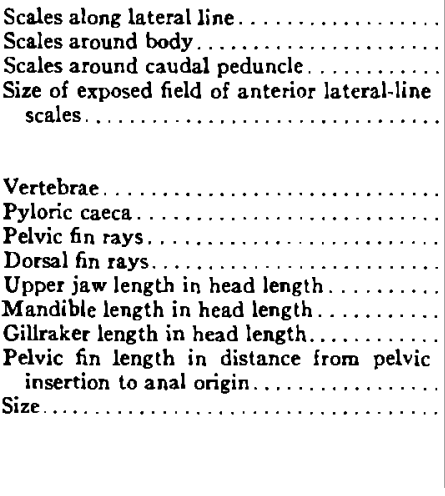 & $\begin{array}{l}52-54 \\
15-23 \\
9-10 \quad(11) \\
(10) \quad 11-13 \quad(14) \\
3.1 \text { to } 3.4 \\
2.3 \text { to } 2.6 \\
11.4 \text { to } 15.4 \\
1.3 \text { to } 1.7 \\
\text { Small; maximum totallength } \\
149 \text { millimeters (Lake Su- } \\
\text { perior) to ca. } 198 \text { millimeters } \\
\text { (Alaska) }\end{array}$ & $\begin{array}{l}{ }^{1}(80) \quad 83-96 \quad(100)^{*} \\
(40) 42-46 \quad(47)^{*} \\
22-24 \\
\text { Notably smaller than adja- } \\
\text { cent scales (scarcely smaller } \\
\text { in small juveniles) } \\
59-63^{*} \\
87-117^{*} \\
(10) \quad 11 \quad(12) \\
(13) 14-1)^{-15} \\
3.9 \text { to } 4.8^{*} \\
2.7 \text { to } 3.1^{*} \\
19.6 \text { to } 27.2^{*} \\
1.7 \text { to } 2.5^{*} \\
\text { Large: maximum weight } \\
\text { about } 5 \text { pounds* }\end{array}$ \\
\hline
\end{tabular}

${ }^{1}$ Koelz $(1929$, p. 562$)$ recorded a Lake Superior specimen of cylindraceus with 74 scales, 10 fewer than his next lowest count from the lake. It is conceivable that this was a hybrid with coulteri

Mountain whitefish, $C$. williamsoni. That species has longer and more numerous gillrakers, numbering 20 to 25 , than do coulteri and cylindraceus.

\section{Distribution and Abundance}

General distribution.-The known range of the pygmy whitefish is confined to Lake Superior and certain waters on the Pacific slope from the headwaters of the Columbia River to south-central Alaska (Fig. 2). The species has not been collected in the Great Lakes other than Lake Superior. Trawling by the Cisco in northern and western Lake Huron in September and October 1952, was too limited to preclude the possibility of its occurrence there. It was not collected in much more extensive trawling in Green Bay, Lake Michigan, May 29-October 26, 1952, in southern Lake Michigan May 8, 1954-March 10, 1955, and in northern Lake Michigan May 14-September 7, 1955. The pygmy whitefish apparently either does not occur or is rare in these waters.

It may be anticipated that future investigation will yield additional records of the pygmy whitefish in the cold streams and deep lakes of the Pacific drainage from the Columbia River system to south-central Alaska. There is as yet no evidence of the existence of the species in the Mackenzie River basin, but it may possibly occur in deep lakes there as it does in Lake Superior. That the pygmy whitefish exists in northern United States or southern Canada, between Lake Superior and the Columbia River drain- 


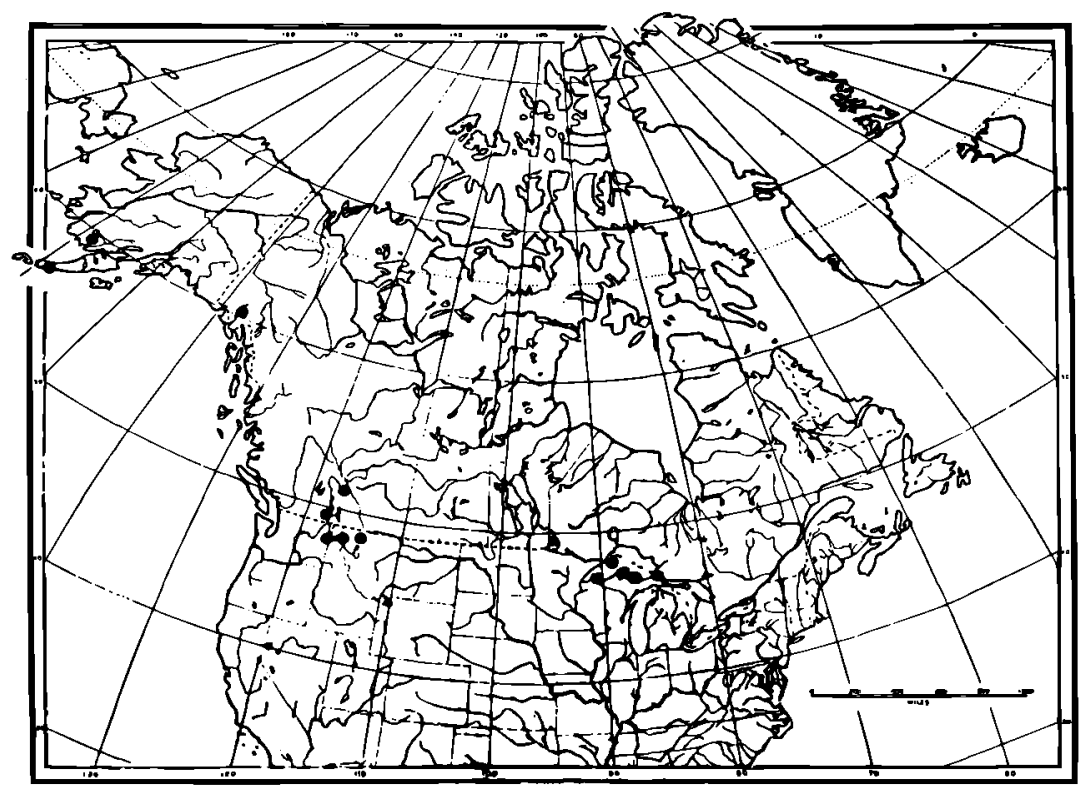

Ficure 2.-Northern North America, showing collection localities for the pygmy whitefish.

age, however, seems unlikely. This region has been fairly well investigated and has few if any waters suitable to the species.

It is probable that Coregonus coulteri was a common and continuously distributed species near the periphery of the ice in late Pleistocene time. The few relict populations known to persist occupy some of the coldest waters of the United States, western Canada, and Alaska. Thus the present disjunct distribution may be regarded as due to survival in suitable habitats following the retreat of the Wisconsin glaciation. The results of radiocarbon analyses have demonstrated the relative recency of the last glaciation (Hough, 1953; Zumberge and Potzer, 1955). Hence, the finding that widely separated stocks of the pygmy whitefish differ little morphologically has a rational historical explanation. If the isolation of stocks was temporally remote, substantial structural differentiation would be expected.

Distribution and abundance in Lake Superior.-In Lake Superior the pygmy whitefish is widely distributed. Collection localities range from the Apostle Islands east to Whitefish Bay (about 290 miles) and north to Isle Royale (Fig. 3, Table 1). The species unquestionably occurs elsewhere. Collecting was restricted to areas with a suitable bottom for trawling where commercial fishing gear was not in use. No trawling was attempted along the entire northern and most of the eastern shore of the lake.

Although relatively few pygmy whitefish have been collected in other waters, Lake Superior has yielded 1,623 specimens. Of these, 68 percent 
Whitefish in Lake Superior

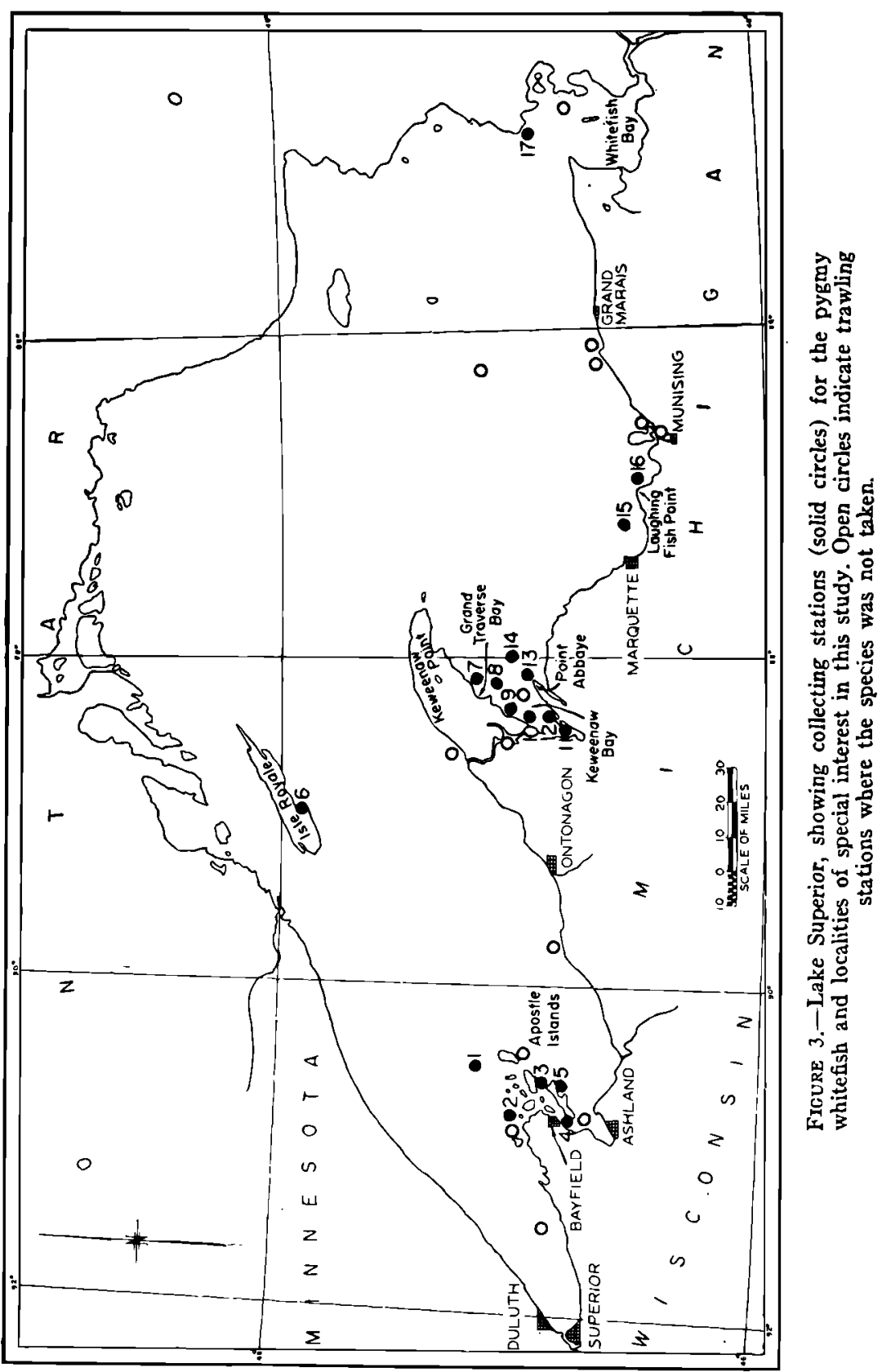


were obtained in Keweenaw Bay (Fig. 3, Stations 9 to 12), 23 percent in Siskiwit Bay, Isle Royale (Station 6), 4 percent off Laughing Fish Point (Station 16), 2 percent in the Apostle Islands (Stations 1 to 5), and the remaining 3 percent at other localities. The number of fish taken at the several stations is not directly indicative of the abundance in these areas because of variation in fishing time. Nevertheless, the pygmy whitefish was more plentiful in Siskiwit Bay and in Keweenaw Bay than elsewhere. In Siskiwit Bay as many as 171 fish were collected in a single 10-minute haul (more than 80 percent were young of the year), and the average in the area was 52 per haul. In Keweenaw Bay (Stations 9 to 12) 85 were obtained from a single haul and the average catch in 74 drags was 15 fish. The maximum catch per haul did not exceed 15 at other stations, except for 20 fish taken in a 9-minute haul at Station 14. At two of the Cisco's major collection areas, the Apostle Islands and Laughing Fish Point, the average catch on dates when pygmy whitefish were taken was only 2 per haul.

Pygmy whitefish were not collected at 14 stations fished during 1953. The open circles of Figure 3 designate localities at which a minimum of 20 minutes of trawling failed to collect the species, even though the catch of other fish indicated that the trawl was operating satisfactorily. Trawling at 9 of these stations was at depths above, below, or near the limits of the known bathymetric distribution of Coregonus coulteri in Lake Superior. Comparison of localities of proper depth indicates that trawling was successful chiefly in a protected habitat. Three of the 5 unsuccessful stations of suitable depth are in exposed situations; 3 of the 4 major sampling areas (Siskiwit and Keweenaw Bays, Apostle Islands) are well protected, and the other (Laughing Fish Point) is partly protected from prevailing winds. In exception to this apparent preference for a protected habitat, the pygmy whitefish was not caught in Munising Bay, Munising, Michigan. Here about 2 hours of trawling on June $17-22$ at depths of 15-39 fathoms failed to take pygmy whitefish, but the lake whitefish was far more abundant than at any other locality fished.

\section{Bathymetric Distribution}

The bathymetric range of the pygmy whitefish at Station 11 in southern Keweenaw Bay (Fig. 3), where 58 percent of our specimens were obtained, extended from 10 to 49 fathoms (Table 9). Although taken at all depths fished, it was most plentiful at 25-39 fathoms; the average maximum rate of capture (37 per 10-minute haul) was at the 30 - to 34 -fathom interval. The distribution was similar throughout the season, but on August 2 many fish were taken at 15-19 fathoms, and on May 11 the only fish caught were at 45-49 fathoms. This latter collection indicated a distribution similar to that at Laughing Fish Point (Station 16) early in 1954. There, on January 11, 40 minutes of trawling at 43-54 fathoms yielded 5 pygmy whitefish, whereas 30 minutes of fishing at the same station on January 7 at 26-40 
TABLE 9. - Numbers of pygmy whitefish captured per 10-minute drag of an otter trawl in southern Keweenaw Bay (Station 11), Lake Superior, 1953

[Number of minutes of trawling in parentheses]

\begin{tabular}{|c|c|c|c|c|c|c|c|}
\hline $\begin{array}{c}\text { Depth' } \\
\text { (fathoms) }\end{array}$ & $\begin{array}{c}\text { May } \\
11\end{array}$ & $\begin{array}{c}\text { July } \\
11\end{array}$ & $\begin{array}{c}\text { August } \\
2\end{array}$ & $\begin{array}{c}\text { September } \\
11\end{array}$ & $\begin{array}{c}\text { October } \\
2-3\end{array}$ & $\begin{array}{c}\text { October } \\
15\end{array}$ & Average \\
\hline $10-14$ & $\ldots$ & $\ldots$ & $\begin{array}{c}0.5 \\
(20)\end{array}$ & $\begin{array}{c}0.0 \\
(10)\end{array}$ & ... & $\begin{array}{l}3.0 \\
(10)\end{array}$ & $\begin{array}{c}1.0 \\
(40)\end{array}$ \\
\hline $15-19 \ldots \ldots \ldots$ & $\ldots$ & $\ldots$ & $\begin{array}{l}22.0 \\
(20)\end{array}$ & $\begin{array}{c}4.0 \\
(10)\end{array}$ & $\begin{array}{c}0.0 \\
(10)\end{array}$ & $\ldots$ & $\begin{array}{l}12.0 \\
(40)\end{array}$ \\
\hline $20-24$ & $\ldots$ & $\ldots$ & $\ldots$ & $\begin{array}{l}2.0 \\
(10)\end{array}$ & $\begin{array}{l}14.5 \\
(20)\end{array}$ & $\begin{array}{l}1.5 \\
(20)\end{array}$ & $\begin{array}{l}6.8 \\
(50)\end{array}$ \\
\hline $25-29$. & $\ldots$ & $\begin{array}{c}0.0 \\
(10)\end{array}$ & $\begin{array}{l}19.7 \\
(30)\end{array}$ & $\begin{array}{l}24.9 \\
(35)\end{array}$ & $\ldots$ & $\begin{array}{l}23.3 \\
(75)\end{array}$ & $\begin{array}{c}21.4 \\
(150)\end{array}$ \\
\hline $30-34$. & $\ldots$ & $\begin{array}{l}41.5 \\
(20)\end{array}$ & $\begin{array}{l}19.2 \\
(40)\end{array}$ & $\begin{array}{l}54.4 \\
(39)\end{array}$ & $\begin{array}{l}32.3 \\
(13)\end{array}$ & $\ldots$ & $\begin{array}{c}37.0 \\
(112)\end{array}$ \\
\hline 35-39. . & $\begin{array}{l}0.0 \\
(6)\end{array}$ & $\ldots$ & $\begin{array}{c}7.0 \\
(10)\end{array}$ & $\ldots$ & $\ldots$ & $\begin{array}{l}51.0 \\
(10)\end{array}$ & $\begin{array}{l}22.3 \\
(26)\end{array}$ \\
\hline $40-44 .$. & $\begin{array}{c}0.0 \\
(58)\end{array}$ & $\ldots$ & $\ldots$ & $\begin{array}{l}40.0 \\
(10)\end{array}$ & $\ldots$ & $\begin{array}{l}10.0 \\
(20)\end{array}$ & $\begin{array}{c}6.8 \\
(88)\end{array}$ \\
\hline $45-49$. & $\begin{array}{l}0.6 \\
(65)\end{array}$ & $\ldots$ & $\ldots$ & $\ldots$ & $\ldots$ & $\ldots$ & $\begin{array}{c}0.6 \\
(65)\end{array}$ \\
\hline
\end{tabular}

1 Placement of individual hauls based on the mean of the shallowest and deepest water fished. Most tows patalleled isobaths in water of nearly constant depth

fathoms failed to take the species. Perhaps pygmy whitefish are confined to waters of considerable depth during the winter and spring.

The average length of pygmy whitefish increased directly with water depth in southern Keweenaw Bay in 1953 (Table 10). Mean total lengths in the combined collections ranged from 71 millimeters ( 2.8 inches) at 10-19 fathoms to 116 millimeters (4.6 inches) at $40-49$ fathoms. (The trend was similar in individual collections.) This relationship was caused by differences in the depth distribution of age groups. All fish collected at the shallowest interval (10-14 fathoms) were yearlings; the percentage of fish of this age declined with increase in depth to 7 percent at $40-44$ fathoms and nil at 45-49 fathoms.

Some seasonal change occurred in the bathymetric distribution of Igroup pygmy whitefish. At depths greater than 29 fathoms, the percentage of I-group fish taken within a specific 5-fathom depth interval increased somewhat with the progress of the season. At the 30- to 34-fathom interval, for example, yearlings made up only 16 percent and 14 percent of the catch on July 11 and August 2, but accounted for 32 percent on September 11 and 65 percent on October 2-3. At 35-39 fathoms the percentage of I-group whitefish was nil on August 2 and 16 on October 15; at $40-44$ fathoms it was 5 on September 11, and 11 on October 15. These increases 
TABLE: 10.-Average tolal length (millineters) of pyginy whilefish caught at different depths in southern Keweenaw Bay (Station 11) Lake Superinr, 1953

[Number of fish in parentheses. Data presented are from preserved fish; 83 were discarded]

\begin{tabular}{|c|c|c|c|c|c|c|c|}
\hline $\begin{array}{c}\text { Depth } \\
\text { (fathoms) }\end{array}$ & $\begin{array}{c}\text { May } 11^{1} \\
\text { July } 11\end{array}$ & $\begin{array}{c}\text { August } \\
2\end{array}$ & $\begin{array}{c}\text { Seplember } \\
11\end{array}$ & $\begin{array}{c}\text { October } \\
2-3\end{array}$ & $\begin{array}{c}\text { October } \\
15\end{array}$ & Average & $\begin{array}{l}\text { Percentage } \\
\text { of yearlings } \\
\text { in catch }\end{array}$ \\
\hline $10-14 \ldots \ldots \ldots$ & $\ldots$ & $\begin{array}{l}69 \\
(1)\end{array}$ & $\ldots$ & $\ldots$ & $\begin{array}{l}80 \\
(3)\end{array}$ & $\begin{array}{l}77 \\
(4)\end{array}$ & 100 \\
\hline $15-19 \ldots$ & $\ldots$ & $\begin{array}{c}70 \\
(39)\end{array}$ & $\begin{array}{l}76 \\
(2)\end{array}$ & $\ldots$ & . & $\begin{array}{c}70 \\
(41)\end{array}$ & 95 \\
\hline 20-24. & $\ldots$ & $\ldots$ & $\ldots$ & $\begin{array}{c}84 \\
(22)\end{array}$ & $\begin{array}{l}78 \\
(3)\end{array}$ & $\begin{array}{c}83 \\
(25)\end{array}$ & 72 \\
\hline $25-29 \ldots$ & $\cdots$ & $\begin{array}{l}103 \\
(59)\end{array}$ & $\begin{array}{c}287 \\
(105)\end{array}$ & $\ldots$ & $\begin{array}{c}94 \\
(171)\end{array}$ & $\begin{array}{c}9.3 \\
(335)\end{array}$ & 49 \\
\hline $30-34$ & $\begin{array}{l}102 \\
(81)\end{array}$ & $\begin{array}{l}105 \\
(28)\end{array}$ & $\begin{array}{c}99 \\
(192)\end{array}$ & $\begin{array}{c}89 \\
(34)\end{array}$ & .. & $\begin{array}{c}99 \\
(335)\end{array}$ & 30 \\
\hline 35-39. & $\ldots$ & $\begin{array}{l}116 \\
(7)\end{array}$ & $\ldots$ & $\ldots$ & $\begin{array}{r}104 \\
(50)\end{array}$ & $\begin{array}{r}105 \\
(57)\end{array}$ & 14 \\
\hline $40.44 \ldots \ldots \ldots$ & $\cdots$ & $\cdots$ & $\begin{array}{l}118 \\
(40)\end{array}$ & $\cdots$ & $\begin{array}{l}113 \\
(19)\end{array}$ & $\begin{array}{l}116 \\
(59)\end{array}$ & 7 \\
\hline $45-49 \ldots \ldots \ldots$ & $\begin{array}{l}116 \\
(4)\end{array}$ & $\cdots$ & $\cdots$ & $\cdots$ & $\cdots$ & $\begin{array}{l}116 \\
(4)\end{array}$ & 0 \\
\hline
\end{tabular}

The collection at $30-34$ fathoms was made July 11 ; that at 45.49 fathoms on May 11

2 Includes 17 fish collected at 30 fathoms and 2 fish from 21 fathoms

in percentage of I-group fish are reflected in the mean lengths of Table 10. Yearlings collected at different depths on the same date showed no significant difference in average length.

The rate of capture of pygmy whitefish on September 7 in Siskiwit Bay (Station 6) was slightly higher at 15-19 and 20-24 fathoms (23 and 24 fish per haul) than at 35-39 fathoms (17 fish per haul). On September 30 more fish were taken in a haul at 10-14 fathoms (171) than at 15-19 fathoms (95), the only depths fished. Most were 0- or I-group fish. Data for collections at other stations in Lake Superior were too scanty for analysis but indicated a vertical distribution according to size and age similar to that in Keweenaw Bay.

\section{Age AND GRowth}

Age was determined for 271 pygmy whitefish collected in Keweenaw Bay (Station 11) on October 2 and 15, 1953, 94 caught in Siskiwit Bay (Station 6) on September 7, 32 taken in the Apostle Island region (Stations 2-5) on May 30-July 30, and 37 from Laughing Fish Point (Station 16), July 13, 1953-January 11, 1954. Scales were mounted in a glyceringelatin medium and diameters within annuli were measured at the magnifcation $\times 84$. Growth calculations were by direct proportion. 
Keweenaw Bay. - Calculated total lengths at the end of each year of life for 123 male and 148 female pygmy whitefish from Keweenaw Bay (Table 11) reveal extraordinarily slow growth. The two oldest fish, both nearing the end of their eighth growing season, were only 5.4 inches long at the time of collection.

TABLE 11. - Average calculated total length (millimeters) and length at caplure of pygmy whitefis/ collected in Keweenaw Bay, October 2 and 15, 1953

\begin{tabular}{|c|c|c|c|c|c|c|c|c|c|c|c|c|}
\hline \multirow{2}{*}{$\begin{array}{c}\text { Age } \\
\text { group }\end{array}$} & \multirow{2}{*}{ Sex } & \multirow{2}{*}{$\begin{array}{c}\text { Number } \\
\text { of } \\
\text { fisl }\end{array}$} & \multicolumn{2}{|c|}{ Total length at capture } & \multirow{2}{*}{$\begin{array}{l}\text { Weight } \\
\text { (grams) }\end{array}$} & \multicolumn{7}{|c|}{ Calcutated length at end of year of life } \\
\hline & & & Inches & Millimeters & & 1 & 2 & 3 & 4 & 5 & 6 & 7 \\
\hline \multirow[t]{2}{*}{$\mathbf{I}$} & Male. & 61 & 3.0 & 76 & 2.3 & 54 & $\ldots$ & -- & $\bar{\ldots}$ & -. & $\ldots$ & - \\
\hline & Female. & $5 i$ & 3.0 & $i 7$ & 2.4 & 55 & $\therefore$ & $\ldots$ & $\cdots$ & $\ldots$ & $\ldots$ & $\cdots$ \\
\hline \multirow[t]{2}{*}{ II } & Male. & 14 & .3 .7 & 94 & 4.7 & 42 & 76 & . & $\ldots$ & $\ldots$ & & $\ldots$ \\
\hline & Female. & 1.5 & 4.0 & 101 & 6.1 & 36 & 76 & . & $\cdots$ & $\cdots$ & $\cdots$ & $\cdots$ \\
\hline \multirow[t]{2}{*}{ III } & Male. & 5 & 4.0 & 102 & 5.9 & 42 & 75 & 95 & $\ldots$ & $\ldots$ & 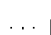 & $\ldots$ \\
\hline & Female. & 10 & 4.2 & 106 & 7.5 & 40 & 75 & 92 & $\cdots$ & $\cdots$ & $\cdots$ & $\cdots$ \\
\hline \multirow[t]{2}{*}{ IV } & Male. & 25 & $4 . ?$ & 106 & 7.8 & 44 & 69 & 87 & 99 & & & \\
\hline & Female. & 26 & 4.7 & 120 & 12.9 & 42 & 69 & 91 & 111 & & . & $\ldots$ \\
\hline \multirow[t]{2}{*}{$\mathrm{V}$} & Male. & 18 & 4.3 & 110 & 8.8 & 44 & 70 & 86 & 97 & 106 & $\ldots$ & . \\
\hline & Female. & 35 & 5.0 & 126 & 15.2 & 41 & 65 & 86 & 104 & 118 & $\ldots$ & $\cdots$ \\
\hline VI & Eemale. & 3 & 5.0 & 128 & 16.1 & 46 & 68 & 90 & 105 & 115 & 123 & \\
\hline VIl & fiemale. & 2 & 5.4 & 136 & 20.4 & 37 & 60 & i9 & 95 & 110 & 122 & 130 \\
\hline Avergee & Male & 123 & 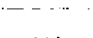 & . & 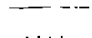 & 49 & $\overline{28}$ & 17 & -- & 9 & -- & \\
\hline increment & Fernale. & 148 & $\cdots$ & $\cdots$ & $\cdots$ & 46 & $\begin{array}{l}20 \\
29\end{array}$ & 21 & 19 & 14 & 10 & 8 \\
\hline Average & Male. & 123 & $\ldots$ & $\ldots$ & $\ldots$ & 49 & 71 & 87 & 98 & 106 & & \\
\hline length & Fcmale. & 148 & $\ldots$ & $\ldots$ & $\ldots$ & 40 & 69 & 88 & 107 & 117 & 123 & 130 \\
\hline Increment & Male. & 123 & $\ldots$ & $\cdots$ & $\ldots$ & 49 & 22 & 16 & 11 & 8 & & .. \\
\hline of average & Fernale. & 148 & $\begin{array}{l}\cdots \\
\cdots\end{array}$ & $\cdots$ & $\cdots$ & 46 & 23 & 19 & 19 & 10 & 6 & 7 \\
\hline
\end{tabular}

Female pygmy whitefish consistently averaged longer and heavier at capture than did males of the same age. The difference in length ranged from 1 millimeter (I group) to 16 millimeters (V group); the weight advantage of the females varied from 0.1 gram (I group) to 6.4 grams (V group). In age-group $\mathrm{V}$, females were 73 percent heavier than males. The annual increments of length indicate a first-year advantage for males (49 millimeters as compared with 46 millimeters for females), nearly equal growth in the second year (28 and 29 millimeters), and more rapid growth for females in the next 3 years. The calculated lengths for the age-groups exhibit some indication of "Lee's phenomenon." Except for the first-year length of age-group I the trend is not sharp, but it is sufficient to produce discrepancies between average increments and increments of the average (Table 11). Comparison of lengths at collection and calculated lengths of fish of the various age groups indicates that the growing seasun may have been nearly completed by the date of collection. 
Despite irregularities in the data, the percentage of males decreased with age. Males made up 51 percent of the fish in age-groups I and II, 45 percent of those in age-groups III and IV, and only 31 percent of age-groups V-VII (only females in VI and VII groups). This trend is reflected in the average age (number of annuli) which was 2.4 for males and 2.9 for females. The complete sample was 45 percent male.

The poor numerical representation of age-groups II and III (in comparison with age-groups I, IV, and V) suggests that year-classes 1950 and 1951 may have been relatively weak. Wide fluctuations in the strength of year classes have been observed frequently in Great Lakes fishes (including coregonines). The small numbers of whitefish in age-groups VI and VII may result from normal mortality rather than weakness of year classes.

With the exception of age-groups I and II, the length-frequency distribution at the time of collection of adjacent age groups of pygmy whitefish in Keweenaw Bay exhibited extensive overlap (Table 12). Length alone,

TABLE 12. - Lenglh-frequency disiribution of age groups of pygmy whitefish collected in Keweenaw Bay, October 2 and 15, 1953

$[\mathbf{M}=$ male; $\mathbf{F}=$ female $]$

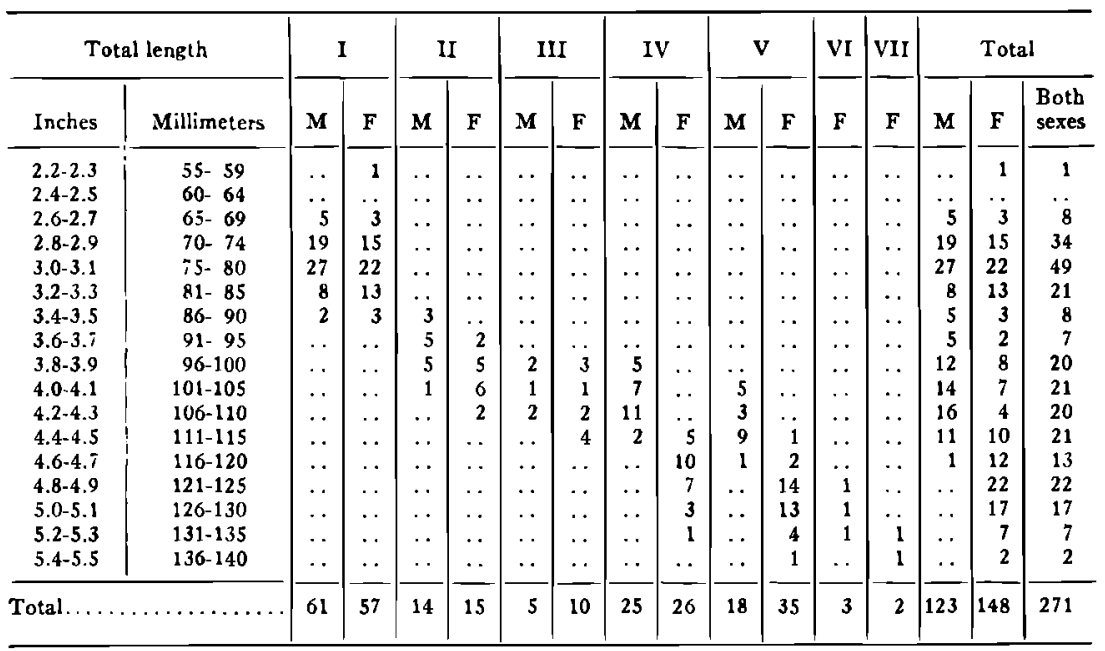

therefore, can be employed with confidence for the identification of all but the largest fish (3.4-3.5 inches) in the I-group but at greater age is undependable. Every length interval beginning with 3.8-3.9 inches included members of 2 to 4 age groups.

Siskiwit Bay, Isle Royale.- The growth rate of pygmy whitefish was even slower in Siskiwit Bay (Table 13) than in Keweenaw Bay. With the exception of the second year of life all calculated annual increments of length were greater in Keweenaw Bay than in Siskiwit Bay. The maximum 
difference in rate was in the fourth year of life of females (11 millimeters in Siskiwit Bay; 19 millimeters in Keweenaw Bay). Despite the more rapid growth in Keweenaw Bay, the data for the two stocks exhibit certain similarities. In both areas, for example, females were larger than males at capture (exception in I-group of Siskiwit Bay). Sex differences of calculated growth also were similar. Males had the higher first-year increments, the growth of the sexes was nearly equal in the second year, and females had the greater increments in later years of life.

TABLE 13. - Average calculated total length (millimeters) and length at capture of pygmy whitefish collected in Siskiwit Bay, Isle Royale, September 7, 1953

\begin{tabular}{|c|c|c|c|c|c|c|c|c|}
\hline \multirow{2}{*}{$\begin{array}{c}\text { Age } \\
\text { group }\end{array}$} & \multirow{2}{*}{ Sex } & \multirow{2}{*}{$\begin{array}{c}\text { Number } \\
\text { of } \\
\text { fish }\end{array}$} & \multicolumn{2}{|c|}{$\begin{array}{c}\text { Total length at } \\
\text { capture }^{1}\end{array}$} & \multicolumn{4}{|c|}{$\begin{array}{c}\text { Calculated length at end } \\
\text { of year of life }\end{array}$} \\
\hline & & & Inches & Millimeters & 1 & 2 & 3 & 4 \\
\hline 0 & Unknown...... & 12 & 1.4 & 36 & . & . & .. & . \\
\hline I & $\begin{array}{l}\text { Male............. } \\
\text { Female....... }\end{array}$ & $\begin{array}{l}17 \\
10\end{array}$ & $\begin{array}{l}2.5 \\
2.3\end{array}$ & $\begin{array}{l}63 \\
59\end{array}$ & $\begin{array}{l}42 \\
41\end{array}$ & $\begin{array}{l}\cdots \\
\cdots\end{array}$ & $\therefore$ & $\begin{array}{l}. \\
\cdots\end{array}$ \\
\hline II & $\begin{array}{l}\text { Male................. } \\
\text { Female...... }\end{array}$ & $\begin{array}{r}22 \\
5\end{array}$ & $\begin{array}{l}3.1 \\
3.2\end{array}$ & $\begin{array}{l}78 \\
81\end{array}$ & $\begin{array}{l}38 \\
37\end{array}$ & $\begin{array}{l}68 \\
67\end{array}$ & $\begin{array}{l}\ldots \\
\cdots\end{array}$ & $\begin{array}{l}. . \\
. .\end{array}$ \\
\hline 111 & $\begin{array}{l}\text { Male.............. } \\
\text { Female....... }\end{array}$ & $\begin{array}{l}18 \\
11\end{array}$ & $\begin{array}{l}3.3 \\
3.5\end{array}$ & $\begin{array}{l}85 \\
88\end{array}$ & $\begin{array}{l}39 \\
32\end{array}$ & $\begin{array}{l}68 \\
62\end{array}$ & $\begin{array}{l}81 \\
80\end{array}$ & $\begin{array}{l}. . \\
\cdots\end{array}$ \\
\hline IV & $\begin{array}{l}\text { Male............. } \\
\text { Female...... }\end{array}$ & $\begin{array}{r}1 \\
10\end{array}$ & $\begin{array}{l}3.6 \\
3.9\end{array}$ & $\begin{array}{r}92 \\
100\end{array}$ & $\begin{array}{l}46 \\
39\end{array}$ & $\begin{array}{l}72 \\
65\end{array}$ & $\begin{array}{l}81 \\
85\end{array}$ & $\begin{array}{l}88 \\
96\end{array}$ \\
\hline $\begin{array}{l}\text { Average } \\
\text { increment }\end{array}$ & $\begin{array}{l}\text { Male........... } \\
\text { Female....... }\end{array}$ & $\begin{array}{l}58 \\
36\end{array}$ & $\cdots$ & $\ldots$ & $\begin{array}{l}40 \\
37\end{array}$ & $\begin{array}{l}29 \\
28\end{array}$ & $\begin{array}{l}13 \\
19\end{array}$ & $\begin{array}{r}7 \\
11\end{array}$ \\
\hline $\begin{array}{l}\text { Average } \\
\text { length }\end{array}$ & $\begin{array}{l}\text { Male ......... } \\
\text { Female . . . . . }\end{array}$ & $\begin{array}{l}\cdots \\
\cdots\end{array}$ & $\begin{array}{l}\cdots \\
\cdots\end{array}$ & $\begin{array}{l}\cdots \\
\cdots\end{array}$ & $\begin{array}{l}40 \\
37\end{array}$ & $\begin{array}{l}68 \\
64\end{array}$ & $\begin{array}{l}81 \\
82\end{array}$ & $\begin{array}{l}88 \\
96\end{array}$ \\
\hline $\begin{array}{l}\text { Increment } \\
\text { of average }\end{array}$ & $\begin{array}{l}\text { Male........... } \\
\text { Female...... }\end{array}$ & $\begin{array}{l}\cdots \\
\cdots\end{array}$ & $\begin{array}{l}\ldots \\
\cdots\end{array}$ & $\begin{array}{l}\cdots \\
\cdots\end{array}$ & $\begin{array}{l}40 \\
37\end{array}$ & $\begin{array}{l}28 \\
27\end{array}$ & $\begin{array}{l}13 \\
18\end{array}$ & $\begin{array}{r}7 \\
14\end{array}$ \\
\hline
\end{tabular}

1 These fish were not weighed because they had been transferred from formalin to alcobol after collection

The sex ratio of Siskiwit Bay fish varied erratically among the age groups, but the oldest (IV) was strongly dominated by females. The numerical abundance of the age groups gives no indication of weakness in the 1950 and 1951 year classes, both of which were poorly represented in Keweenaw Bay.

The Apostle Islands. - The limited collection of pygmy whitefish from the Apostle Islands shows that growth was more rapid in this region than in Siskiwit or Keweenaw Bay. The average calculated total lengths in millimeters at the end of each year of life ${ }^{3}$ for 32 fish collected May 30July 30, 1953, are shown below (number of fish in parentheses):

S All age groups were combined. Because of difficulty in determining whether a new annulus had formed on scales of some fish collected May 30, only average lengths computed from scale measurements within visible annuli are included in the table. 


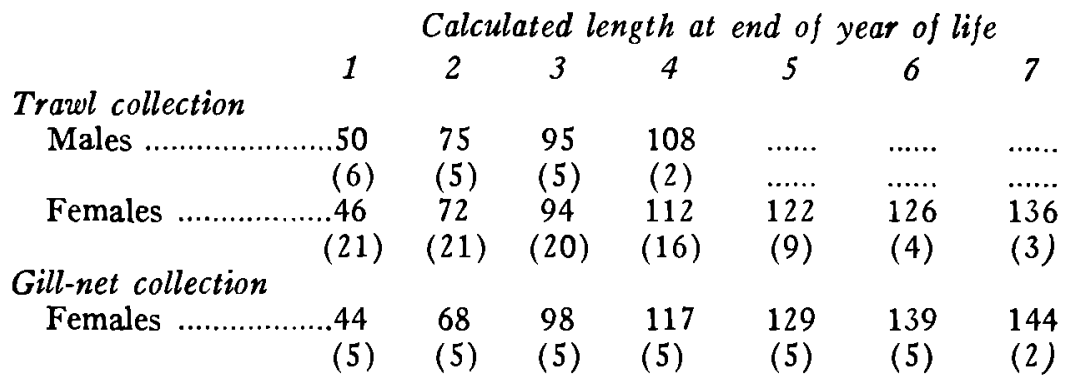

The growth pattern for the sexes was similar to that described for Siskiwit and Keweenaw Bays. The average length of fish from trawl collections in the Apostle Islands was greater than that of fish from Keweenaw Bay (Table 11) for both sexes and at all ages, with the single exception of females at the end of the first year. Differences in rate of growth in these two regions were of about the same magnitude as differences in rate of growth between Keweenaw and Siskiwit Bays.

The single gill-net collection of pygmy whitefish is shown separately from trawl collections because the gill nets (1-inch mesh, extension measure) were obviously selective for fast-growing fish of large size. That this species attains a larger size in the Apostle Islands than elsewhere in Lake Superior is suggested by its capture in gill nets in this area only although other localities were fished with identical gear. Whereas 900 feet of 1 -inch-mesh gill net captured 6 fish at this station, 27,600 feet of net set within the known bathymetric range of the species at other localities failed to take it. A total of 8,400 feet of this net was set in the Keweenaw Bay region, where the species was known to be abundant.

Laughing Fish Point.- The collection of pygmy whitefish from Laughing Fish Point for which ages were determined was limited to 25 fish of the I-group, and only 12 of other age groups. Despite minor discrepancies, presumably because of the small sample, a growth rate similar to that in Keweenaw Bay is indicated. A summary of the data for fish of age groups I to VI follows (number of fish in parentheses):

\begin{tabular}{|c|c|c|c|c|c|c|}
\hline & Cal & lated & engt & end & year & life \\
\hline & 1 & 2 & 3 & 4 & 5 & 6 \\
\hline Males & $\ldots .48$ & 79 & 92 & 102 & 106 & \\
\hline & (22) & (6) & (3) & (3) & (1) & \\
\hline Females & $\begin{array}{c}\ldots 46 \\
(15)\end{array}$ & $\begin{array}{r}68 \\
(6)\end{array}$ & $\begin{array}{r}90 \\
(5)\end{array}$ & $\begin{array}{c}106 \\
(4)\end{array}$ & $\begin{array}{l}118 \\
(2)\end{array}$ & $\begin{array}{l}123 \\
\text { (1) }\end{array}$ \\
\hline
\end{tabular}

As in the other regions calculated length of females was less than that of males for the first two years, about equal during the third, and exceeded that of males for the fourth and later years of life.

Length of young of the year. - Collections of young-of-the-year pygmy whitefish in Lake Superior indicated that fish of this age were showing good growth during September and October (Table 14). Although the 
numbers of fish collected were usually small, their average lengths showed a progressive increase from 36 and 35 millimeters on September 7 and 10, to 45 and 49 millimeters on October 5 and 21.

Growth in Bull and McDonald Lakes, Montana.-That growth rate of pygmy whitefish was faster in Bull and McDonald Lakes, Montana, than in Lake Superior is shown by the curves of Figure 4, which compare cal-

TABLE 14. - Length of O-group pygmy whilefish in Lake Superior, 1953

\begin{tabular}{|c|c|c|c|c|}
\hline \multirow{2}{*}{ Collection locality ${ }^{1}$} & \multirow{2}{*}{ Date } & \multirow{2}{*}{$\begin{array}{c}\text { Number } \\
\text { of } \\
\text { fish }\end{array}$} & \multicolumn{2}{|c|}{$\begin{array}{l}\text { Total length } \\
\text { (millimeters) }\end{array}$} \\
\hline & & & Range & Average \\
\hline 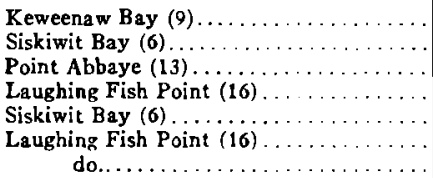 & $\begin{array}{l}\text { Sept. } 5 \\
\text { Sept. } 7 \\
\text { Sept. } 10 \\
\text { Sept. } 14 \\
\text { Sept. } 30 \\
\text { Oct. } 5 \\
\text { Oct. } 21\end{array}$ & $\begin{array}{r}1 \\
12 \\
5 \\
13 \\
137 \\
9 \\
3\end{array}$ & $\begin{array}{l}32-40 \\
31-39 \\
33-39 \\
35-49 \\
40-54 \\
47-51\end{array}$ & $\begin{array}{l}31 \\
36 \\
35 \\
37 \\
42 \\
45 \\
49\end{array}$ \\
\hline
\end{tabular}

1 Station numbers (Fig. 3) are in parentheses

culated lengths at the end of each year of life for fish from these waters and from Keweenaw and Siskiwit Bays. Data for fish from the Montana waters are as follows (number of fish in parentheses):

Lake McDonald

Calculated length at end of year of life 4

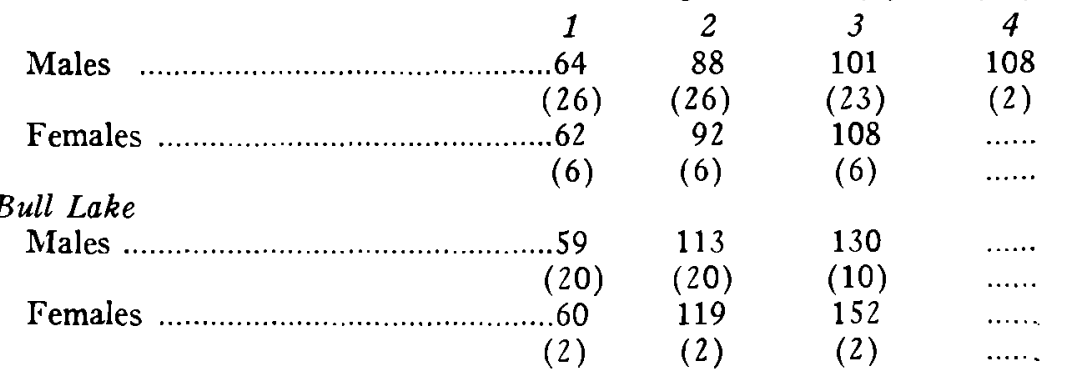

At the age of 3 years, the average length of male pygmy whitefish from Bull Lake was 60 percent greater than in Siskiwit Bay; for females this percentage was 85 . The increment during the second year of life, which showed the widest deviation, was nearly double that of Lake Superior fish. Almost no change in growth rate was shown by the fish from Bull Lake during the first 2 years of life, whereas this rate declined about 40 percent during the second year in Keweenaw Bay. An even sharper decline (about

4 Since the dates of collection were December 26 and January 12 (Bull Lake) and November 17 (Lake McDonald), an annulus at the periphery of the scales was assumed and length at col. lection was considered equivalent to calculated length. 


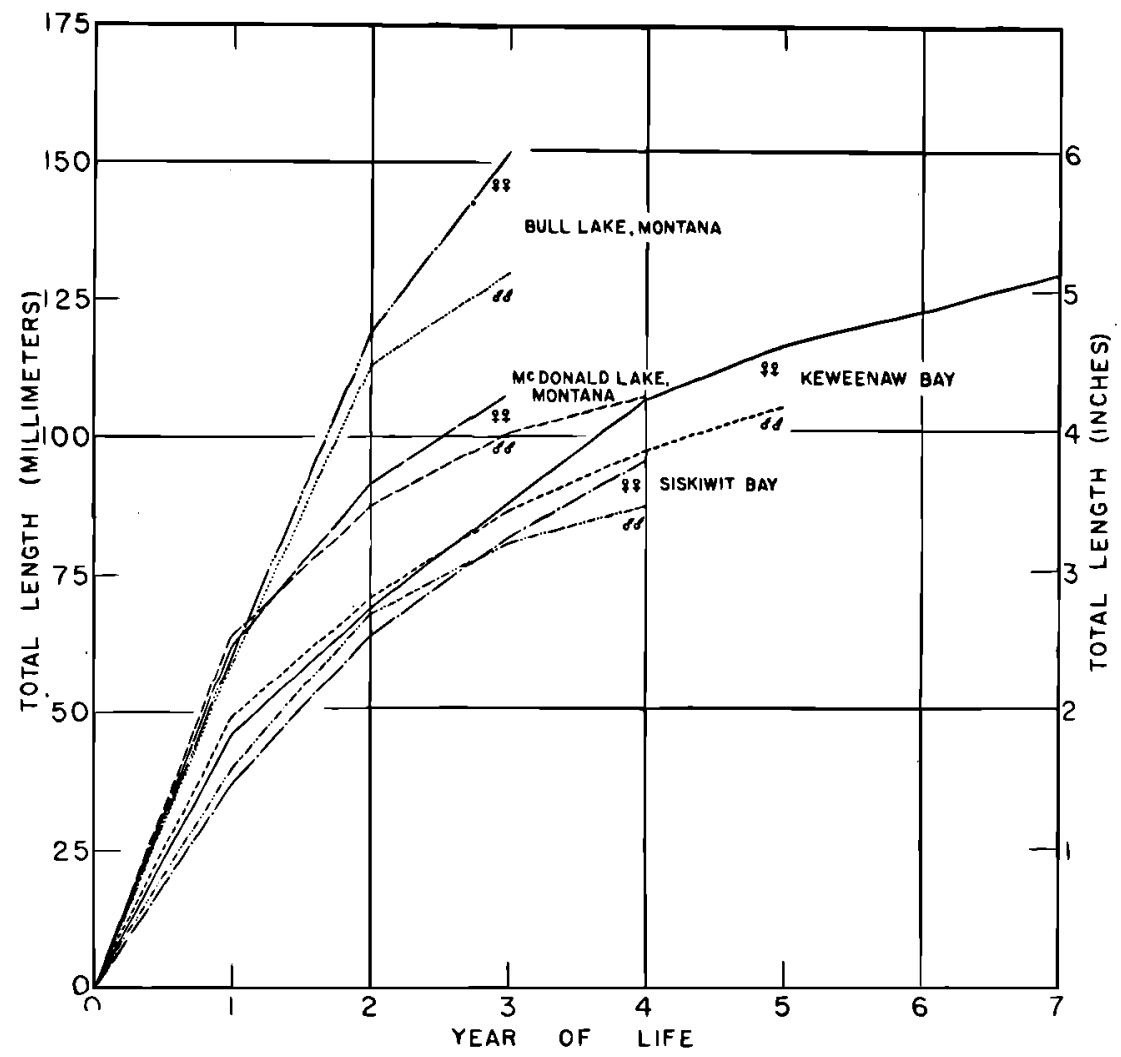

FIGure 4.-Calculated growth in length of pygmy whitefish from Bull and McDonald Lakes, Montana, and Keweenaw and Siskiwit Bays, Lake Superior.

55 percent) in growth rate during the second year was indicated by pygmy whitefish of the Lake McDonald collection. Although these fish attained a first-year calculated length slightly greater than that of fish from Bull Lake, their growth curves during subsequent years were roughly parallel with those of fish from Lake Superior.

\section{Length-Frequency Distribution}

The length-frequency distribution of 1,521 pygmy whitefish collected in Lake Superior in 1952-1954 (Table 15) is given separately for the four principal areas of capture. Collections from Keweenaw Bay and vicinity are tabulated in part according to sex and date.

The total length of pygmy whitefish taken by trawling in Lake Superior ranged from 1.2 to 5.7 inches. Only the young of the year and yearlings stood out reasonably well in the length-frequency distribution. The $O$ group 


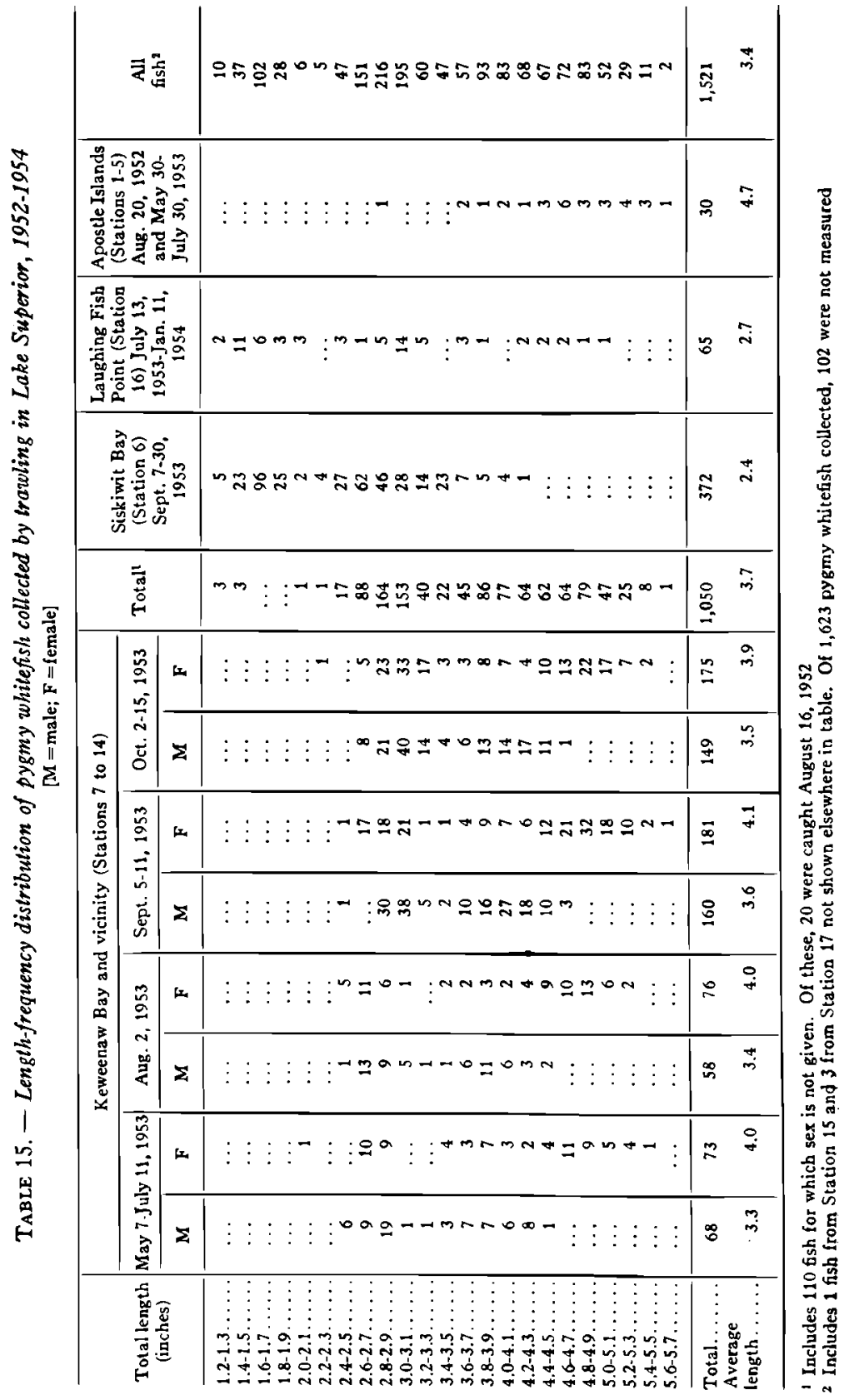


was well separated from the I group in the Keweenaw Bay and Laughing Fish Point regions, but in the slowly growing population of Siskiwit Bay it tended to overlap the I group slightly by September 30 (all fish less than 2.0 inches long were of the $O$ group). In Keweenaw Bay age-group I was reasonably distinct from older age groups in the collections of May 7 to August 2 (all fish less than 3.2 inches), and September 5-11 (less than 3.4 inches), but by October the largest of the yearlings had overtaken the smallest fish of the II group. Probably the demarcation of the I group would have been even less distinct if age-groups II and III had been represented by strong year classes; both were rather poorly represented in 1953. In Siskiwit Bay, where age-groups II and III were well represented, the length-frequency distribution of age-group I overlapped broadly those of older age groups.

Separation of males from females in the length-frequency distribution for pygmy whitefish from Keweenaw Bay emphasizes the sexual differences in growth rate and life span (p. 181). All fish longer than 4.7 inches were females (Table 15), except for a 5.0-inch male (age-group VI) collected at Station 15 on August 12, 1953.

The mean length of pygmy whitefish caught by trawling in Lake Superior was 3.4 inches. The length averaged 2.4 to 4.7 inches at the major collecting areas. The smallest average lengths (2.4 and 2.7 inches) were at Siskiwit Bay and Laughing Fish Point, where 38 to 40 percent of the fish caught were young of the year, and where few large fish were taken. In the Apostle Islands region, in contrast, few young fish were collected; the average length was 4.7 inches.

\section{REPRODUCTION}

Age and size at maturity.-All male pygmy whitefish of age-group II or older in collections from Keweenaw Bay, October 2-15, 1953, and from Siskiwit Bay, Isle Royale, September 7, were sexually mature (Table 16). A few I-group males ( 7 percent) from Keweenaw Bay also were mature.

Relatively few II-group females were mature ( 3 of 15 in Keweenaw Bay on October 2-15, none of 5 in Siskiwit Bay on September 7, and 3 of 11 on September $30^{5}$ ). Of the III-group females, 6 of 10 from Keweenaw Bay and 8 of 11 from Siskiwit Bay were mature and all fish of older age groups were mature in both collections. The age at which 50 percent or more of the pygmy whitefish were mature in Lake Superior was 2 years for males and 3 years for females.

In Weisel and Dillon's (1954) collections from Bull Lake, Montana, all I-group pygmy whitefish were sexually mature. These fish were much larger than the Lake Superior fish, however (p. 185), and were apparently taken from a spawning aggregation, in which immature fish would not be expected. Mature yearling males also occurred in fish from a spawning

5 These 11 fish were part of a large collection in which all but 12 were members of age-group I (the twelfth fish belonged to the III-group). Ages were determined by the examination of scales, but no scale measurments were made 


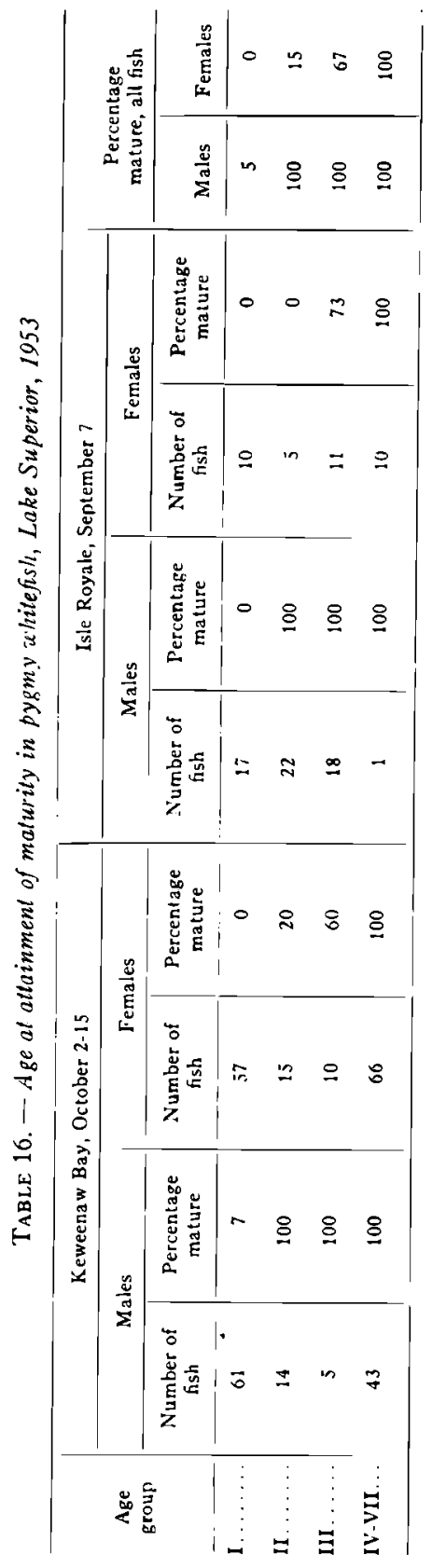


aggregation collected in Lake McDonald, Montana, November 17, 1936.

The data on length at which pygmy whitefish attain sexual maturity (Table 17) are based on 799 fish collected in Keweenaw Bay between August 2 and October 15, 1953, after seasonal development of the gonads had progressed sufficiently to permit accurate determination of maturity. Some males were mature at a total length of 3.0-3.1 inches and some females at 3.8-3.9 inches. Percentage maturity increased progressively with increasing length. Fifty percent or more of the fish were mature at the 3.4- to 3.5-inch class in males and at the 4.2- to 4.3-inch interval for females. All larger fish of each sex were mature.

\section{TABLE 17. - Length al attainment of maturify in pygmy whitefish, Keweenaw Bay, Lake Superior}

[Stations 9, 11, and 13, August 2-October 15, 1953]

\begin{tabular}{|c|c|c|c|c|}
\hline \multirow{2}{*}{$\begin{array}{c}\text { Total } \\
\text { length } \\
\text { (inches) }\end{array}$} & \multicolumn{2}{|c|}{ Males } & \multicolumn{2}{|c|}{ Females } \\
\hline & $\begin{array}{l}\text { Number of } \\
\text { fish }\end{array}$ & $\begin{array}{l}\text { Percentage } \\
\text { mature }\end{array}$ & $\begin{array}{l}\text { Number of } \\
\text { fish }\end{array}$ & $\begin{array}{l}\text { Percentage } \\
\text { mature }\end{array}$ \\
\hline 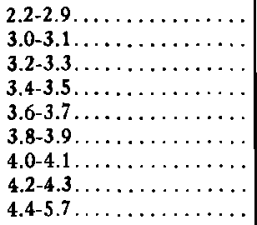 & $\begin{array}{r}83 \\
83 \\
20 \\
7 \\
22 \\
40 \\
47 \\
38 \\
27\end{array}$ & $\begin{array}{r}0 \\
7 \\
25 \\
71 \\
100 \\
100 \\
100 \\
100 \\
100\end{array}$ & $\begin{array}{r}87 \\
55 \\
18 \\
6 \\
9 \\
20 \\
16 \\
14 \\
207\end{array}$ & $\begin{array}{r}0 \\
0 \\
0 \\
0 \\
0 \\
10 \\
31 \\
86 \\
100\end{array}$ \\
\hline
\end{tabular}

Sex ratio.- Treatment of the sex ratio of different age groups (p. 182) brought out a somewhat erratic variability ${ }^{6}$ but demonstrated an unmistakable trend for males to be scarce or lacking in the older age groups, thus providing an explanation for the predominance of females in most collections. The scarcity of older males in combination with their relatively slow growth led to an unusual relationship between sex ratio and length of pygmy whitefish in Keweenaw Bay in 1953. A summary of data tabulated according to length and sex in Table 15 yields the following:

$\begin{array}{ccc}\text { Total length } & \text { Number of } & \text { Percentage } \\ \text { (inches) } & \text { fish } & \text { males } \\ 2.0-3.5 & 422 & 55 \\ 3.6-3.9 & 115 & 66 \\ 4.0-4.3 & 134 & 74 \\ 4.4-4.5 & 59 & 41 \\ 4.6-4.7 & 59 & 7 \\ 4.8-5.7 & 151 & 0\end{array}$

6 The unreliability of sex ratios shown by small numbers of fish was emphasized by collections in Siskiwit Bay. In this area 22 of 27 II-group fish collected September 7 were males, but all of 11 II-group fish collected on September 30 at this station were females. This apparent segregation of the sexes probably was not typical, as it was not observed in other collections. 
Males were only slightly more numerous than females at 2.0-3.5 inches, reached a predominant position at $4.0-4.3$ inches, and dwindled rapidly at 4.6-4.7 inches, the largest length interval in which they were represented at all.

Fecundity.-Maturing eggs were counted in the ovaries of 63 pygmy whitefish collected in Lake Superior in 1953. Egg production ranged from 93 to 597 and averaged 362 (Table 18). The average number of eggs

\section{TABLE 18. - Production of eggs by pygmy whitefish in Lake Superior, 1953}

ICollection localities and dates were as follows: 57 fish from Keweenaw Bay (Station 11). September 11 October $15 ; 3$ (the smallest in the series, $87-91$ millimeters) from Siskiwit Bay (Station 6), September 30; 1 (the largest fish, 149 millimeters) from the Apostle Islands (Station 3), July 29; and 2 (117 and 123 millimeters) off Laughing Fish Point (Station 16), October 21]

\begin{tabular}{|c|c|c|c|c|c|c|}
\hline \multirow{2}{*}{$\begin{array}{l}\text { Total } \\
\text { length } \\
\text { (inches) }\end{array}$} & \multirow{2}{*}{$\begin{array}{l}\text { Average } \\
\text { weight } \\
\text { (grams) }\end{array}$} & \multirow{2}{*}{$\begin{array}{c}\text { Number } \\
\text { of } \\
\text { fish }\end{array}$} & \multicolumn{2}{|c|}{ Number of eggs } & \multicolumn{2}{|c|}{$\begin{array}{c}\text { Number of eggs per gram } \\
\text { of fish? }\end{array}$} \\
\hline & & & Range & Average & Range & Average \\
\hline $\begin{array}{l}3.4-3.9 \ldots \ldots \ldots \\
4.0-4.4 \ldots \ldots \ldots \ldots \\
4.5-4.9 \ldots \ldots \ldots \\
5.0-5.4 \ldots \ldots \ldots \\
5.5-5.9 \ldots \ldots \ldots\end{array}$ & $\begin{array}{r}5.9(1) \ldots \\
8.9(8) \ldots \\
13.5(22) . \\
17.0(17) \\
21.9(2) .\end{array}$ & $\begin{array}{r}4 \\
9 \\
26 \\
20 \\
4\end{array}$ & $\begin{array}{r}93-156 \\
146-285 \\
248-440 \\
385-586 \\
489-597\end{array}$ & $\begin{array}{l}121 \\
235 \\
344 \\
457 \\
531\end{array}$ & $\begin{array}{l}21-30 \\
20-31 \\
20-31 \\
26-26\end{array}$ & $\begin{array}{l}26 \\
27 \\
26 \\
26 \\
26\end{array}$ \\
\hline
\end{tabular}

1 Numbers of fish weighed (in parentheses) show basis of estimates of numbers of eggs per gram of fish

Mean of values for individual fish

produced by fish of each $1 / 2$-inch length group rose from 121 at $3.4-3.9$ inches to 531 at 5.5-5.9 inches. The mean production of eggs per gram of weight ranged between the narrow limits of 20 and 31 and averaged 26 or 27 for all length groups.

In the graphical presentation of egg production (Fig. 5), a line drawn by inspection through the points representing egg production of individual fish has a sigmoid form. The section of steepest rise, between the lengths of 4.3 and 4.7 inches, depicts an average increase of about 160 eggs per $1 / 2$-inch increase of length. A decrease in rate to about 100 eggs per $1 / 2$-inch of length is indicated by the section of the curve for fish of 5.4 to 5.9 inches. Although the values were rather uniformly distributed about the curve, figures for some individuals were scattered. The greatest deviation for fish of about equal size was shown by two fish (5.3 and 5.4 inches long) which had egg counts of 388 and 586, a difference of 51 percent.

The ovaries of a 117-millimeter female pygmy whitefish collected off Laughing Fish Point on October 21, 1953, contained 78 partly resorbed eggs which had apparently been retained from the previous spawning season. These eggs equalled 36 percent of the average production (Fig. 5) for a fish of its calculated length (108 millimeters) at the approximate time of its failure to expel all of its eggs. Since many eggs may have been resorbed before the time of collection, this fish may not have spawned at all during the previous year. The presence of the partly resorbed eggs in 


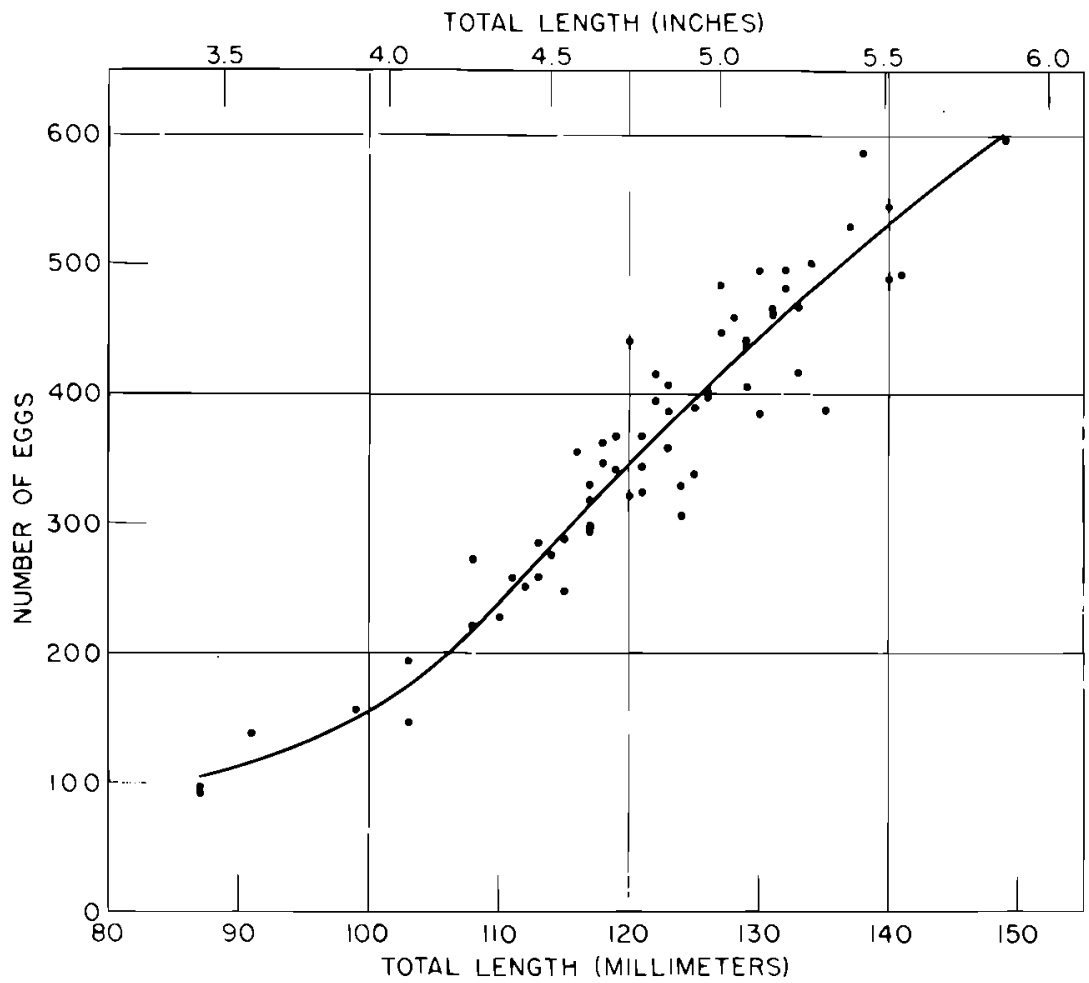

Figure 5.-Relationship of length of fish to number of eggs in ovaries of pygmy whitefish. The data are summarized in Table 18.

the ovary did not interfere with production because the 295 new eggs in its ovaries were only 6 percent below the average number for three other fish of the same length.

Residual mature eggs were rarely seen in other ovaries, although one spent female collected January 11, 1954, had 15 such eggs and another had 1.

Time and locality of spawning.-Although no collections of pygmy whitefish were made during the breeding season, spawning in the Laughing Fish Point region undoubtedly occurred during November or December 1953. Ovaries of 2 females of the last fall collection (October 21) were not yet ripe, although they composed 15 percent of the total weight of the fish ${ }^{7}$ and firmly packed the body cavity with large eggs. (Random samples of 25 eggs from each measured in a measuring trough had an average diameter of 2.0 millimeters.) The egg size of the Lake Superior fish was

7 The average percentage of the total weight made up by ovaries of 25 mature females collected ia Keweenaw Bay on October 15 was also 15. 
about the same as that of 2 pygmy whitefish from the spawning run in Bull Lake, Montana. In the Bull Lake fish the average diameter of 11 residual eggs of a nearly spent female was 2.0 millimeters and the average diameter of the eggs of a nearly ripe fish was 2.1 millimeters. Testes of Lake Superior males were not yet ripe in the October collection (not milky in color, as were those of the spawning Bull Lake fish). The gonads of 2 spent, mature males and 2 females collected January 11 appeared to have recovered fully from spawning. The testes were not milky and were smaller than in fish of the October collections. Some of the 15 residual mature eggs found in the ovaries of one of the females were discolored and disfigured; apparently resorption had begun.

In comparison with the November or December spawning of pygmy whitefish in Lake Superior, fish caught in Bull Lake (Weisel and Dillon, 1954) were in breeding condition during the December 26-January 12 period. Kendall (1921) found Alaska fish of this species in spawning condition in one collection in August and in another (from a different locality) in November. Pygmy whitefish caught November 17, 1936, in Glacier National Park, Montana, were in breeding condition and obviously represented a spawning aggregation.

The breeding grounds of the pygmy whitefish in Lake Superior are not known. The capture of young fish in relatively shallow water (13-18 fathoms) at Keweenaw Bay, Point Abbaye, and Siskiwit Bay (Stations 9,13 , and 6) together with the tendency of yearling fish to inhabit the shallower waters of Keweenaw Bay offers some evidence that spawning occurs in shallow water. On the other hand, young fish were caught at 16 to 32 fathoms at Laughing Fish Point (Station 16).

At Bull Lake, Montana, pygmy whitefish in breeding condition were caught in shallow water near the mouth of a tributary stream (Weisel and Dillon, 1954), and the spawning fish from Lake McDonald also were presumably taken in shallow water.

\section{FOOD}

Stomach contents were examined from 112 pygmy whitefish 2.4 to 5.9 inches long collected May 7, 1953-January 11, 1954, at 5 stations in Lake Superior. Samples used for food studies were taken at random or comprised all individuals caught in a single drag of the trawl. Because contents of individual stomachs were often too small for satisfactory measurement, a single volume determination (by liquid displacement in a sedimentation tube graduated to 0.01 cubic centimeter) was made for the aggregate of each food item from an entire collection.

Crustacea occurred in 95 percent of the stomachs of pygmy whitefish and composed 77 percent of the total food volume (Table 19). Ostracods and amphipods (principally or entirely Pontoporeia), were the chief components, comprising 75 percent of the volume. Ostracods were not found in stomachs from two small collections off Laughing Fish Point but were well represented in fish from other localities. Amphipods occurred in 15 to 
TABLE 19. - Percentage frequency of occurrence and (in parentheses) percentage of total volume composed by food items in stomachs of pygmy whitefish in Lake Superior, 1953 [All collection dates were in 1953, except for that of January 11, 1954. Tr indicates volume less than 0.5 percent. Taxonomic groups in footnotes show principal components of higher groups.]

\begin{tabular}{|c|c|c|c|c|c|c|c|c|}
\hline \multirow{2}{*}{ Item } & \multicolumn{3}{|c|}{ Keweenaw Bay } & \multirow{2}{*}{$-\frac{\begin{array}{c}\text { Siskiwit } \\
\text { Bay }\end{array}}{\text { Sept. } 7}$} & \multirow{2}{*}{$\begin{array}{c}\text { Apostle } \\
\text { Islands } \\
\text { May 30, } \\
\text { July 29 }\end{array}$} & \multicolumn{2}{|c|}{ Laughing Fish Point } & \multirow{2}{*}{ Total } \\
\hline & May 7.11 & Aug. 2 & Oct. 15 & & & Oct. 21 & $\begin{array}{c}\text { Jan. 11, } \\
1954\end{array}$ & \\
\hline Total leng th (inches). & $3.5-5.4$ & $3.9-5.4$ & $2.7-5.2$ & $2.4-4.3$ & $3.7-5.9$ & $2.9-4.9$ & $4.4-5.0$ & $2.4-5.9$ \\
\hline Number of stomachs. & 11 & 7 & 41 & 31 & 15 & 3 & 4 & 112 \\
\hline Crustacea . & $\begin{array}{l}100 \\
(85)\end{array}$ & $\begin{array}{l}100 \\
(\mathrm{~B} 2)\end{array}$ & $\begin{array}{l}100 \\
(94)\end{array}$ & $\begin{array}{c}87 \\
(68)\end{array}$ & $\begin{array}{l}100 \\
(93)\end{array}$ & $\begin{array}{l}100 \\
(95)\end{array}$ & $\begin{array}{r}50 \\
(1)\end{array}$ & $\begin{array}{r}95 \\
(77)\end{array}$ \\
\hline Cladocera $^{1} \ldots \ldots \ldots$ & $\cdots$ & $\cdots$ & $\begin{array}{l}{ }^{2} 15 \\
(t r)\end{array}$ & $\cdots$ & $\cdots$ & $\begin{array}{l}367 \\
(t r)\end{array}$ & $\cdots$ & $\begin{array}{c}7 \\
(t r)\end{array}$ \\
\hline Copepoda 4. & $\begin{array}{l}91 \\
(9)\end{array}$ & $\ldots$ & $\begin{array}{c}12 \\
(t r)\end{array}$ & $\begin{array}{l}29 \\
(5)\end{array}$ & $\begin{array}{c}20 \\
(\mathrm{t} r)\end{array}$ & $\begin{array}{c}67 \\
(58)\end{array}$ & $\cdots$ & $\begin{array}{l}26 \\
(2)\end{array}$ \\
\hline Ostracoda........ & $\begin{array}{l}82 \\
(6)\end{array}$ & $\begin{array}{l}100 \\
(9)\end{array}$ & $\begin{array}{c}93 \\
(94)\end{array}$ & $\begin{array}{l}52 \\
(2)\end{array}$ & $\begin{array}{l}100 \\
(37)\end{array}$ & $\cdots$ & $\cdots$ & $\begin{array}{c}76 \\
(31)\end{array}$ \\
\hline Mysidacea $^{3} \ldots \ldots$ & $\begin{array}{l}18 \\
(2)\end{array}$ & $\ldots$ & $\cdots$ & $\ldots$ & $\begin{array}{c}13 \\
(t r)\end{array}$ & $\ldots$ & $\cdots$ & $\stackrel{4}{(t r)}$ \\
\hline Amphipoda ${ }^{8} \ldots \ldots$ & $\begin{array}{c}73 \\
(68)\end{array}$ & $\begin{array}{l}100 \\
(73)\end{array}$ & $\begin{array}{c}15 \\
(t r)\end{array}$ & $\begin{array}{c}58 \\
(61)\end{array}$ & $\begin{array}{l}100 \\
(56)\end{array}$ & $\begin{array}{c}67 \\
(37)\end{array}$ & $\begin{array}{l}50 \\
(1)\end{array}$ & $\begin{array}{c}52 \\
(44)\end{array}$ \\
\hline Hydracarina ........ & $\cdots$ & $\cdots$ & $\stackrel{2}{(t r)}$ & $\cdots$ & $\ldots$ & $\ldots$ & $\ldots$ & $\begin{array}{c}1 \\
(t r)\end{array}$ \\
\hline Insecta $\ldots \ldots \ldots \ldots$ & $\begin{array}{c}36 \\
(t r)\end{array}$ & $\begin{array}{l}100 \\
(18)\end{array}$ & $\begin{array}{l}42 \\
(6)\end{array}$ & $\begin{array}{c}71 \\
(21)\end{array}$ & $\begin{array}{l}100 \\
(5)\end{array}$ & $\begin{array}{c}67 \\
(t+)\end{array}$ & $\begin{array}{l}50 \\
(1)\end{array}$ & $\begin{array}{l}62 \\
(9)\end{array}$ \\
\hline Larvae and pupae & $\begin{array}{c}36 \\
(\mathrm{tr})\end{array}$ & $\begin{array}{l}100 \\
(18)\end{array}$ & $\begin{array}{l}22 \\
(3)\end{array}$ & $\begin{array}{c}71 \\
(21)\end{array}$ & $\begin{array}{l}87 \\
(4)\end{array}$ & $\begin{array}{c}67 \\
(t r)\end{array}$ & $\begin{array}{c}25 \\
(t r)\end{array}$ & $\begin{array}{l}52 \\
(8)\end{array}$ \\
\hline Adults. . & $\ldots$ & $\begin{array}{c}29 \\
(t r)\end{array}$ & $\begin{array}{l}29 \\
(3)\end{array}$ & $\begin{array}{c}3 \\
(t r)\end{array}$ & $\begin{array}{l}33 \\
\text { (1) }\end{array}$ & $\cdots$ & $\begin{array}{l}50 \\
(1)\end{array}$ & $\begin{array}{r}20 \\
(1)\end{array}$ \\
\hline Pelecypoda ${ }^{\circ}$. & & . & . & $\begin{array}{c}42 \\
(11)\end{array}$ & $\begin{array}{l}53 \\
(2)\end{array}$ & $\begin{array}{l}33 \\
(5)\end{array}$ & $\ldots$ & $\begin{array}{l}20 \\
(3)\end{array}$ \\
\hline Fish eggs ${ }^{10}$. & $\begin{array}{c}46 \\
(15)\end{array}$ & $\cdots$ & $\cdots$ & $\ldots$ & $\cdots$ & $\cdots$ & $\begin{array}{l}100 \\
(98)\end{array}$ & $\begin{array}{c}8 \\
(11)\end{array}$ \\
\hline
\end{tabular}

1 Daphnia ${ }^{2}$ Ephippia presumed to be of Daphria ${ }^{3}$ Both ephippia and adult Daphnia ${ }^{4}$ Cyclops, Mesocyclops, Epischura, Senecella, Diaptomus, Liminocalanus 5 Mysis OPontoporeia 'Cryplochironomus, Prodiamesa - Hymenoptera, Diptera, Hemiptera, Coleoptera P Pisidium conventus 10 Coregonus

100 percent of the stomachs in the different collections and composed from 1 to 73 percent of the total volume. As many as 285 ostracods or 140 amphipods occurred in a single stomach. Copepods were in 26 percent of the stomachs ( 2 percent of the total volume) but were usually incidental in the diet of fish more than 3.5 inches long. Cladocera (partly in the form of ephippia, presumably of Daphnia or closely related forms) and Mysis (which was known to be abundant at several of the collection stations) were unimportant items. 
Insects were found in 62 percent of the stomachs and made up 9 percent of the food of pygmy whitefish. Larvae and pupae of aquatic forms (principally Chironomidae) occurred in all collections and in 52 percent of the stomachs but composed only 8 percent of the total volume and did not exceed 21 percent of the food volume in any single collection. Adult insects (undoubtedly taken on or near the lake bottom) were present in 20 percent of the stomachs but made up only 1 percent of the volume. Of the other invertebrates found, larval clams (Sphaeriidae) occurred in 20 percent (3 percent of the volume). Only a single Hydracarina was found.

Fish eggs, presumably coregonine, occurred in the collections of May 7-11 (46-percent frequency of occurrence; 15 percent of the volume) and January 11 (in each of 4 stomachs containing food and comprising 98 percent of the total volume). As many as 30 whole eggs and 29 egg shells were in a single stomach in the January 11 collection. Stomach contents of fish on this date were thus markedly different from those of 3 stomachs collected at the same station on October 21, when copepods and amphipods were the principal food. When available, fish eggs are perhaps important in the diet of pygmy whitefish. In support of this conjecture, Kendall (1921) found from 1 to 18 small salmonid eggs in stomachs of 4 of 5 pygmy whitefish collected at Lake Aleknagik, Alaska, August 2, 1912.

Small quantities of finely divided organic detritus were found in 8 of 21 stomachs that were collected in May. (Possibly this material was equivalent to the "indeterminable mush" reported by Kendall [1921] in stomachs of four pygmy whitefish collected in Lake Aleknagik, Alaska, July 20, 1909.) Sand grains-as many as 27 in a single stomach - were present in 10 of the 112 fish examined.

That copepods are extremely important to small fish was shown by stomach analyses of 5 young individuals collected off Point Abbaye (Station 13) on September 10, 1953, and 12 caught in Siskiwit Bay (Station 6) on September 7 (data not shown in Table 19). Their diet was composed almost entirely of copepods (18 to 144 per stomach); in addition, chironomid larvae and pupae contributed a small proportion of the food of the fish from Point Abbaye and a single cladoceran occurred in stomachs of each of 2 of the 12 fish from Siskiwit Bay.

\section{Associated Species}

Twelve species or groups of species (the latter not specifically identified) were collected with the pygmy whitefish in Lake Superior. Estimates of the "degree of association" have been made in terms of percentage occurrence in trawl hauls that took pygmy whitefish and percentage occurrence at stations (and on the same dates and depths) at which Coregonus coulteri was collected (Table 20).

The most common associates of the pygmy whitefish were cottids, which occurred in 87 percent of the hauls and at 88 percent of the stations. The species taken most often was Cottus cognatus; Myoxocephalus quadri- 
TABLE 20. - Associates of the pygmy whitefish in Lake Superior

[The ranking of each species or group of species is expressed in terms of its percentage frequency of occurrence in 99 trawl hauls and at 17 stations where pygmy whitefish were taken]

\begin{tabular}{|c|c|c|}
\hline \multirow{2}{*}{ Species } & \multicolumn{2}{|c|}{$\begin{array}{l}\text { Percentage frequency of } \\
\text { occurrence }\end{array}$} \\
\hline & $\begin{array}{c}\text { In individual } \\
\text { hauls }\end{array}$ & At stations \\
\hline 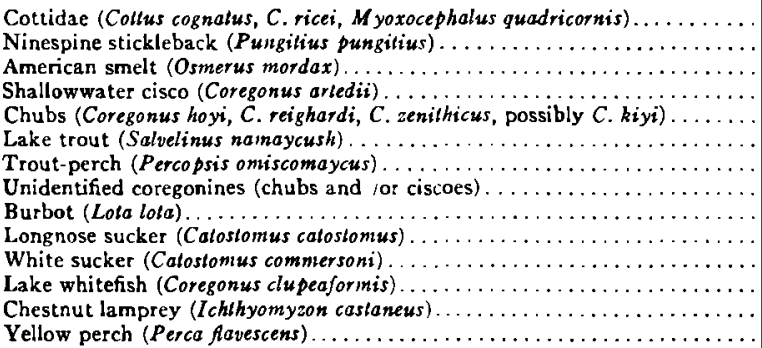 & $\begin{array}{r}87 \\
81 \\
63 \\
36 \\
36 \\
57 \\
34 \\
34 \\
18 \\
15 \\
4 \\
2 \\
1 \\
0\end{array}$ & $\begin{array}{l}88 \\
76 \\
59 \\
71 \\
65 \\
41 \\
41 \\
35 \\
18 \\
12 \\
12 \\
6 \\
6 \\
6\end{array}$ \\
\hline
\end{tabular}

cornis $^{8}$ occurred in numbers only in the deeper waters. The ninespine stickleback was next in importance ( 81 percent of the hauls; 76 percent of the stations), followed by the smelt, shallowwater cisco (lake herring), and chubs. The latter group was composed of 3 (possibly 4) species. Ciscoes, chubs, and Coregonus spp. (unidentified small specimens), when considered as a group, occurred in 84 percent of the hauls and at 88 percent of the stations. Lake trout and trout-perch were other important associates of the pygmy whitefish. Longnose suckers, burbot, lake whitefish, white suckers, chestnut lampreys, and yellow perch were much less common, occurring only in occasional trawl hauls or collection stations. Absent from the list was the round whitefish, closest relative of the pygmy whitefish in Lake Superior (chiefly a resident of shallower waters). With the exception of four young ( 1.5 to 1.6 inches in total length) caught in the Apostle Island region on July 29, 1953, and a 3.5-inch yearling caught west of Grand Marais, Michigan, on June 14, 1953, Coregonus cylindraceus was not taken by trawling in Lake Superior. The Cyprinidae, Percidae, and Centrarchidae, dominant groups of American fishes, are notable for their scarcity or absence in the deep cold waters of Lake Superior where C. coulteri lives.

8 The fourhorn sculpin, better known to most North American ichthyologists as the deepwater sculpin, Triglopsis thompsoni Girard, is chiefly a circumpolar marine fish. In certain large lakes in northern Europe and North America there occur isolated populations that are presumably relicts of independent invasions from the sea near the close of the Pleistocene. This freshwater ecotype contrasts with the saltwater fish in the smaller size, the reduction in number and development of ossified plates on the body, and the weakening or loss of the four rugose ridges or knobs on the top of the head (Berg and Popoy, 1932; Berg, 1949). A number of subspecies have been established on variations, mainly in the characters mentioned (Berg and Popov, 1932). Whether or not any of these have a genetic basis is a matter for conjecture. The populations from Lake Onega, Russia, and the Great Lakes are strikingly similar. Until the nature of the variations is more clearly understood we concur with Vladykov (1933) in adopting the binomial designation for all populations of Myoxocepbolus quodricornis (Linnaeus). 


\section{ACKNOWLEDGMENTS}

We express our thanks and appreciation to the colleagues who have assisted in this study. The operations of the research vessel Cisco were under the general direction of James W. Moffett. Stanford H. Smith assisted in the supervision of the field work. Other fishery biologists who aided in making the field collections were W. S. Glidden, Richard Ryder, Clifford Tetzloff, and LaRue Wells. Karl E. Menzel assisted in the laboratory work. David C. Chandler, Harry B. Herrington, and the late J. Speed Rogers identified invertebrates from the stomachs. Specimens under their care were loaned by the following persons: Ernest A. Lachner and Leonard P. Schultz, U. S. National Museum; C. C. Lindsey, University of British Columbia; George S. Myers and Norman J. Wilimovsky, Stanford University; and George F. Weisel, Montana State University. John R. Dymond, Clarence F. Pautzke, and W. B. Scott supplied information. Andrew Starrett translated material from Russian. Ralph Hile edited the manuscript and made suggestions. William Cristanelli prepared the illustrations.

\section{Literature Cited}

BERG, LEO S.

1940. Classification of fishes, both recent and fossil. Trav. Inst. Zool., Acad. Sci. U.R.S.S. Tome 5, Livr. 2 , pp. 87-517.

1949. Fresh water fishes of the U.S.S.R. and adjoining countries. Acad. Sci. U.S.S.R., Vol. 3, pp. 931-1381. [In Russian]

Berg, Leo S., and A. Popov

1932. A review of the forms of Myoxocephalus quadricornis (L.). C. R. Acad. Sci., U.R.S.S., No. 6, pp. 152-160.

BöHLKE, J.

1953. A catalogue of the type specimens of recent fishes in the Natural History Museum of Stanford University. Stanford Ich. Bull., Vol. 5, pp. 1-168.

Carl, G. Clifford, and W. A. Clemens

1948. The fresh-water fishes of British Columbia. Brit. Col. Prov. Mus., Handbook No. 5, 132 pp. [2nd ed., 1953]

Cockerell, T. D. A.

1913. Observations on fish scales. Bull. U. S. Bur. Fish., Vol. 32 (1912), pp. 117-174.

DYMOND, J. R.

1943. The coregonine fishes of northwestern Canada. Contrib. Roy. Ont. Mus. Zool. No. 24, Trans. Roy. Can. Inst., Vol. 24, Part 2, pp. 171-231.

1947. A list of the freshwater fishes of Canada east of the Rocky Mountains with keys. Roy. Ont. Mus. Zool., Misc. Publ. 1, 36 pp. [Mimeographed]

Eigenmann, Carl H.

1894. Results of explorations in western Canada and the northwestern United States. Bull. U. S. Fish Comm., Vol. 14 (1894), pp. 101-132.

Eigenmann, Carl H., and Rosa Smith Eigenmans

1892. New fishes from western Canada. Am. Nat., Vol. 26, pp. 961-964.

Evermann, Barton Warren, and Edmund lee Goldsborough

1907. A check list of the freshwater fishes of Canada. Proc. Biol. Soc. Wash., Vol. 20, pp. 89-119.

Evermann, Barton W., and Hugh M. SMith

1896. The whitefishes of North America. Rept. U. S. Comm. Fish and Fish., (1894), pp. 283-324. 
Halkett, Andrew

1913. Check list of the fishes of the Dominion of Canada and Newfoundland. Ottawa. $138 \mathrm{pp}$.

Hovgr, JACK L.

1953. Revision of the Nipissing stage of the Great Lakes. Ill. Acad. Sci. Trans., Vol. 46, pp. 133-141.

International Commission on ZoOlogical Nomenclature

1953. Decisions on zoological nomenclature taken by the Fourteenth International Congress of Zoology, Copenhagen, 1953. (Francis Hemming, ed.). London, Metcalf and Cooper, Ltd., xxix +135 pp.

Jordan, David Starr, and Barton Warren Evermann

1896-1900. The fishes of North and Middle America. Bull. U. S. Nat. Mus., No. 47, (4 parts), 3,313 pp.

1911. A review of the salmonoid fishes of the Great Lakes, with notes on the whitefishes of other regions. Bull. U. S. Bur. Fish., Vol. 29 (1909), pp. 1-41.

Jordan, David Starr, Barton Warren Evermann, and Howard Walton Ciark

1930. Check list of the fishes and fishlike vertebrates of North and Middle America north of the northern boundary of Venezuela and Colombia. Rept. U. S. Comm. Fish. (1928), Pt. 2, iv + 670 pp.

Jordan, David Stark, and John Otterbein Sinyder

1909. Description of a new whitefish (Coregonus oregonius) from McKenzie River, Oregon. Proc. U. S. Nat. Mus., Vol. 36, pp. 425-430.

Kendali, William C.

1917. A second record for the Coulter's whitefish (Coregonus coulteri Eigenmann). Copeia, No. 45, pp. 54-56.

1921. Further observations on Coulter's whitefish (Coregonus coulteri Eigenmann). Copeia, No. 90, pp. $1-4$.

Koelz, Walter

1929. Coregonid fishes of the Great Lakes. Bull. U. S. Bur. Fish., Vol. 43, Part II, pp. $297-643$.

LEGENDRE, VIANNEY

1954. Key to game and commercial fishes of the Province of Quebec. Vol. 1. The freshwater fishes. First English Edition. Soc. Can. Ecol., Montreal, 180 pp.

Martin, W. R.

1949. The mechanics of environmental control of body form in fishes. Univ. Toronto Stud., Biol. Series No. 58, Pub. Ont. Fish. Res. Lab. No. 70, 91 pp.

Moffett, James W.

1954. Fisheries knowledge increased through research vessel. The Fisherman, Vol. 22 , No. 3, pp. 7, 13-14.

Mrers, George S.

1932. A new whitefish, Prosopium snyderi, from Crescent Lake, Washington. Copeia, 1932, No. 2, pp. 62-64.

Regan, C. Tate

1914. The systematic arrangement of the fishes of the family Salmonidae. Ann. Mag. Nat. Hist., Ser. 8, Vol. 13, pp. 405-408.

SChultz, Leonard P.

1936. Keys to the fishes of Washington, Oregon and closely adjoining regions. Univ. Wash. Pub. Biol., Vol. 2, pp. 103-228.

1941. Fishes of Glacier National Park Montana. U. S. Dept. Int., Cons. Bull. No. $22, \mathrm{v}+42 \mathrm{pp}$. 
Shapovalov, Leo, and Wimliam A. Dill

1950. A check list of the fresh-water and anadromous fishes of California. Cal. Fish and Game, Vol. 36, pp. 382-391.

SNYDER, JOHN OTTERBEIN

1917. Coulter's whitefish. Copeia, No. 50, pp. 93-94.

1919. Three new whitefishes from Bear Lake, Idaho and Utah. Bull. U. S. Bur. Fish., Vol. 36 (1917-18), pp. 1-9.

VLADYKOV, VADIM D

1933. Biological and oceanographic conditions in Hudson Bay. 9. Fishes from the Hudson Bay region (except the Coregonidae). Contrib. Canad. Biol. and Fish., N. S., Vol. 8, No. 2, pp. 13-61.

WeISEl, George F., and JoHN B. Dillon

1954. Observations on the pygmy whitefish, Prosopium coulteri, from Bull Lake, Montana. Copeia, 1954, No. 2, pp. 124-127.

WILIMOVSKY, NoRMAN J.

1954. List of the fishes of Alaska. Stanford Ich. Bull., Vol. 4, pp. 279-294.

WYNNE-EDWARDS, V. C.

1947. The Yukon Territory. In: North West Canadian Fisheries Surveys in 19441945. Bull. Fish. Res. Bd. Can., No. 72, pp. 6-20.

1952. Freshwater vertebrates of the Arctic and Subarctic. Bull. Fish. Res. Bd. Can., No. 94,28 pp.

Zumberge, James H., and J. E. Potzger

1955. Pollen profiles, radiocarbon dating, and geologic chronology of the Lake Michigan basin. Science, Vol. 121, pp. 309-311. 